The Asia-Pacific Research and Training Network on Trade (ARTNeT) is an open regional network of research and academic institutions specializing in international trade policy and facilitation issues. IDRC, UNCTAD, UNDP, ESCAP and WTO, as core network partners, provide substantive and/or financial support to the network. The Trade and Investment Division of ESCAP, the regional branch of the United Nations for Asia and the Pacific, provides the Secretariat of the network and a direct regional link to trade policymakers and other international organizations.

The ARTNeT Working Paper Series disseminates the findings of work in progress to encourage the exchange of ideas about trade issues. An objective of the series is to publish the findings quickly, even if the presentations are less than fully polished. ARTNeT Working Papers are available online at www.artnetontrade.org. All material in the Working Papers may be freely quoted or reprinted, but acknowledgment is requested, together with a copy of the publication containing the quotation or reprint. The use of the working papers for any commercial purpose, including resale, is prohibited.

\section{Disclaimer:}

The designations employed and the presentation of the material in this Working Paper do not imply the expression of any opinion whatsoever on the part of the Secretariat of the United Nations concerning the legal status of any country, territory, city or area, or of its authorities, or concerning the delimitation of its frontiers or boundaries. Where the designation "country or area" appears, it covers countries, territories, cities or areas. Bibliographical and other references have, wherever possible, been verified. The United Nations bears no responsibility for the availability or functioning of URLs. The views expressed in this publication are those of the author(s) and do not necessarily reflect the views of the United Nations. The opinions, figures and estimates set forth in this publication are the responsibility of the author(s), and should not necessarily be considered as reflecting the views or carrying the endorsement of the United Nations. Any errors are the responsibility of the author(s). Mention of firm names and commercial products does not imply the endorsement of the United Nations. 


\title{
Papua New Guinea and the Natural Resource Curse
}

\author{
Nayda Avalos, ${ }^{*}$ Veronica Gonzales Stuva, ${ }^{*}$ Adam Heal, $\dagger$ \\ Kaoru Lida, ${ }^{*}$ and Naohito Okazoe*
}

Please cite this paper as: Nayda Avalos, Veronica Gonzales Stuva, Adam Heal, Kaoru Lida, and Naohito Okazoe (2013). Papua New Guinea and the Natural Resource Curse.

ARTNeT Working Paper Series No. 128, July, 2013, Bangkok, ESCAP.

\section{Available at www.artnetontrade.org.}

\footnotetext{
*Students in the University of Michigan Public Policy Programme. This paper was undertaken for United Nations ESCAP as part of the Applied Policy Seminar under which students work with a client organization. This project fulfills part of the degree requirements for the Masters in Public Policy Degree.

†Staff member at United Nations ESCAP, Trade and Investment Division.

The authors would like to thank ARTNeT and ESCAP for their technical support, and in particular Ronald Duncan, Simi George, David Harding, Mia Mikic, Mary Matthews, Heini Salonen, and Marin Yari for providing helpful comments and suggestions on earlier drafts. This work was carried out with the aid of a grant from the International Development Research Centre (IDRC), Canada, and is part of an ARTNeT Phase III Research Programme initiative. All errors or omissions are of course the authors' own. Any inquiries can be directed to heal@un.org.
} 
Abstract: Several empirical studies have found that when exports are concentrated in natural resources countries experience slower rates of economic growth. Various potential channels for this relationship have been identified including Dutch disease, volatility in the terms of trade, and impacts on governance. This paper explores whether Papua New Guinea (PNG), a resource rich state in the South Pacific, displays signs of suffering from the natural resource curse. The paper finds some evidence of Dutch disease in the decline of local manufacturing. This may also be exacerbated by large scale exports of liquefied natural gas (LNG) in future years. In addition, the paper finds that extractive industry governance is a pressing challenge for PNG and makes suggestions for reform in revenue management and spending.

JEL Classification: Q33, Q34, O13

Key words: Papua New Guinea, natural resources, natural resource curse, extractive industries, Extractive Industries Transparency Initiative (EITI), Dutch disease, good governance 


\section{Executive Summary}

The 'natural resource curse' refers to the observation that some natural resource-rich countries experience lower economic growth than some natural resource-poor countries. For countries like Papua New Guinea (PNG), which rely on the extraction of natural resources (NR), the possibility of such a 'curse' is a pressing concern.

Studies have identified three channels that could lead to a negative relationship between an abundance of natural resources and lower economic growth. These are: (i) Dutch disease, under which a real appreciation of the currency leads to a decline of non-NR tradable sectors such as manufacturing; (ii) high volatility in the terms of trade, which can lower the efficiency of economic activities; and (iii) governance weakness induced by competition over control of resources and leading to sub-optimal policies including ineffective spending of NR revenues.

In the case of PNG, recent data suggests that the country is experiencing some symptoms of Dutch disease. And future risks are likely to be exacerbated by increased exports from the large Liquefied Natural Gas (LNG) project coming on-stream in the near future. PNG is also susceptible to pronounced changes in its terms of trade, threatening the productivity of the whole economy.

However, weak governance is the single factor most likely to undermine prospects for sustainable growth. Data shows that the rents coming from natural resource activities are not being effectively spent and are failing to translate into improvements in economic and social indicators. Institutional factors such as rent seeking, corruption, poor governance, and underdeveloped human capital could continue to hinder PNG's successful use of its resource rents.

To address these issues, the government of PNG must implement policies that improve macroeconomic management and lift the country's institutional quality. The main policy recommendation of this paper is the establishment of an auditing working group consisting of government officials and non-governmental members (including civil society representatives such as professional experts), whose function would be to oversee the efficiency of the overall Natural Resource Revenue Management, including natural resource revenue collection and its expenditure. This entity could be called the Accountability in Natural Resource Management Working Group (ANRMWG) and would provide both advice and auditing. 
Political leaders should see the ANRMWG as a driver of improved governance. Besides achieving more effective management of natural resources, ANRMWG could also provide lessons for civil society on how to effectively monitor the government in order to promote accountability. By improving accountability and the functioning of its institutions, PNG could turn the natural resource curse into a blessing. 


\section{Contents}

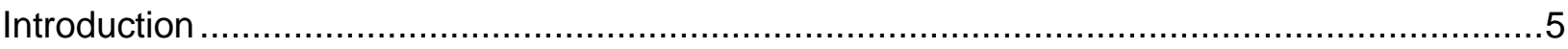

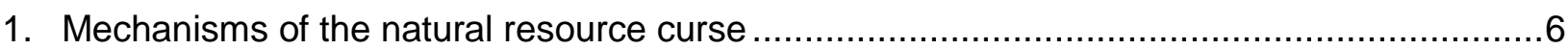

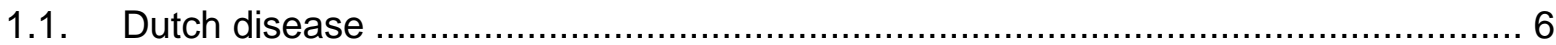

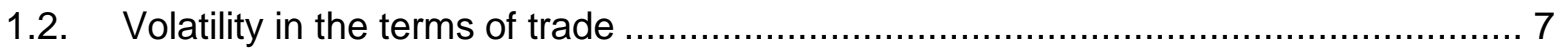

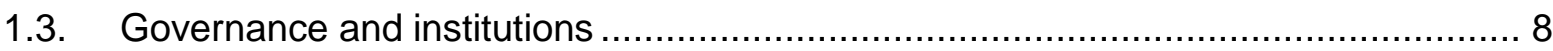

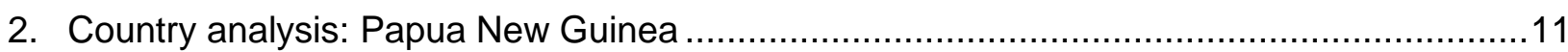

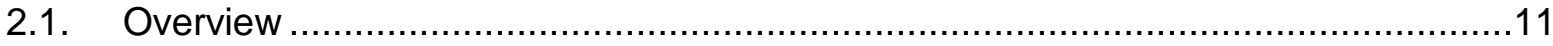

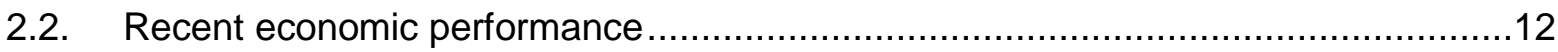

2.3. Role of natural resources in the Papua New Guinea economy ..............................18

2.4. Evidence that Papua New Guinea is affected by the natural resource curse ..........25

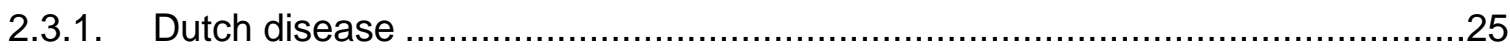

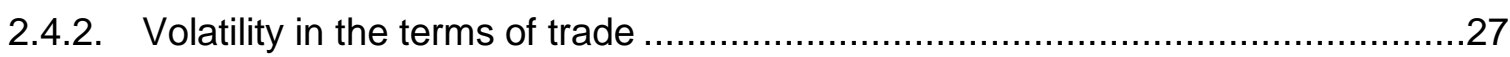

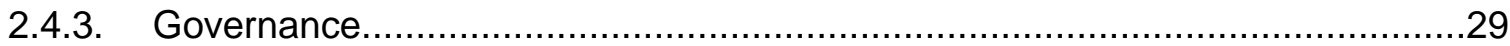

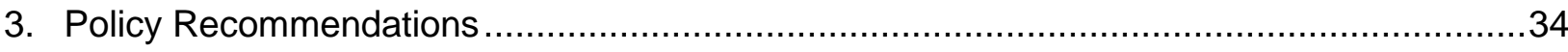

3.1. Mitigating the damage from Dutch disease ......................................................

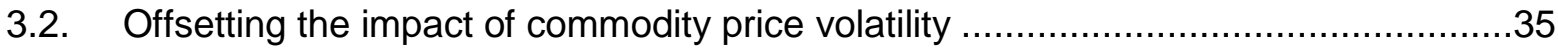

3.3. Building a better relationship with natural resource producing companies ................36

3.4. Improving exchange rate policies ............................................................. 38

3.5. More effective spending of natural resource revenue ..........................................39

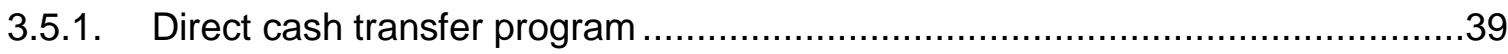

3.5.2. Extractive Industries Transparency Initiatives (EITI) ....................................40

3.5.3. An auditing working group with non-governmental members..........................41

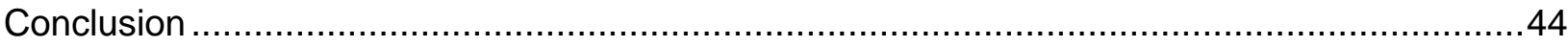

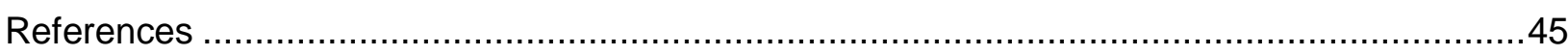

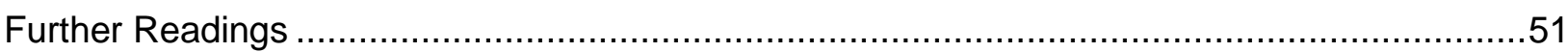




\section{List of Figures}

Figure 1: Relationship between natural resources and economic growth

Figure 2: Real GDP growth in Papua New Guinea (1995-2011)

Figure 3: Sectoral composition of GDP in Papua New Guinea at current prices

Figure 4: Papua New Guinea's exports and imports (\% of GDP) (1994-2011)

Figure 5: Natural resource rents in Papua New Guinea (\% of GDP) (1990-2010)

Figure 6: Export prices (\% change)

Figure 7: Papua New Guinea's tax revenue structure (\% of total revenue) (2012)

Figure 8: Papua New Guinea's real effective exchange rate and natural resource rents (1998-2011)

Figure 9: Papua New Guinea's manufacturing value added and Natural Resource rents

(\% of GDP) (1980-2011)

Figure 10: Papua New Guinea's net barter terms of trade and natural resource rents

(2001-2011)

Figure 11: Papua New Guinea's net barter terms of trade and GDP growth (2001-2011)

Figure 12: Papua New Guinea's governance quality index (1996-2011)

Figure 13: Natural resource rents and control of corruption

Figure 14: Natural resource rents and government effectiveness

Figure 15: Natural resource rents and human development

Figure 16: Natural resource rents and GDP per capita

\section{List of Tables}

Table 1: Papua New Guinea's budget structure

Table 2: Agriculture and other non-mineral exports, classified by commodity (\% of agriculture exports)

Table 3: Mineral exports, classified by commodity (\% of mineral exports)

Table 4: Total labor force, agriculture labor force, and change in mineral labor index 


\section{Introduction}

In recent decades, many natural resource-rich countries in Asia, Africa, the Middle East, and Latin America have suffered from low economic growth, even as some natural resource-poor countries have achieved dramatic economic transformations. Whereas endowments of valuable natural resources appear to be a fortuitous national blessing, they often do not translate into widespread prosperity. In order to explain this discrepancy, scholars have undertaken considerable research on the potential relationship between the abundance of natural resources and poor economic performance, a relationship known as the 'natural resource curse.'

This study focuses on Papua New Guinea (PNG), a country located in the southwestern Pacific Ocean, which is endowed with a variety of natural resources, including oil, gas and minerals. The purpose of this paper is to study the operation of the natural resource curse in this country and identify policies that could help PNG better manage its natural resource endowments and promote economic growth. Successful management of its natural resources could turn the natural resource curse into a blessing for its people.

The paper has the following structure: Section 1 reviews the claims in the literature on the natural resource curse, including possible "channels of transmission". Section 2 analyzes the situation of PNG and considers evidence that it has been a victim of the curse. Section III proposes specific policy recommendations for PNG to address the identified weaknesses and improve management of its natural resource sector in order to boost prospects for sustainable growth. 


\section{Mechanisms of the natural resource curse}

In general, natural resource-rich countries have experienced lower economic growth than natural resource-poor countries. Sachs and Warner (1995) report a negative relationship between GDP growth per capita between 1970 and 1989 and the share of NR exports in 1971 in a sample of 97 developing countries. Frankel (2012) also observes lower average economic growth between 1970 and 2009 in countries with a higher share of mineral exports. This phenomenon is called the "natural resource curse" (Auty 1993, 2001, Auty and Mikesell, 1998).

But there is not yet a consensus amongst scholars. Some developed countries, like Norway, have successfully used NR revenues for economic growth (Overseas Development Institute, 2006). And results from cross-country comparisons have also been queried. For example, Alexeev and Conrad (2009) argue that the effects of resource endowments could be hindered by the relative shortness of the time period examined. Canuto and Cavallori (2012) suggest that intangible wealth in the form of governance quality is the determining factor in economic growth, not natural resource abundance.

Whatever the merits of economic studies to date, policy makers can benefit from studying potential transmission channels and identifying appropriate policies to mitigate the downsides of resource-led expansion, while enhancing prospects for inclusive growth. Therefore this review aims to outline the primary channels of causation between natural resources abundance and slower economic growth. These are: Dutch disease, volatility in the terms of trade, and impacts of NR-wealth on governance and institutions.

\subsection{Dutch disease}

Dutch disease is referred to as the co-existence within the traded goods sector of booming and lagging subsectors (Corden and Neary, 1982). According to this theory, increases in NR exports can cause a large exchange rate appreciation, leading to the decline of non-NR tradable sectors such as manufacturing, (which is here referred to as a 'lagging sector'). An increase in NR-export revenues causes an increase in the demand for goods and services in the non-tradable sector which pushes up prices relative to prices in the tradable sector which are internationally determined. This results in an appreciation of the real exchange rate. ${ }^{1}$

\footnotetext{
${ }^{1}$ Real exchange rate is defined as the relative price of non-tradable to tradable goods (Corden and Neary, 1982).
} 
This in turn leads to an increase in wages in the non-tradable sector, causing the non-NR tradable sectors such as manufacturing to shrink (sometimes called "indirect de-industrialization").

Direct shifts of resources between sectors also cause a shrinking of non-NR tradable sectors, including manufacturing. Labor shifts to the NR-tradable sector from the non-tradable and non-NR tradable sectors because wages in the NR-sector rise due to large foreign inflows. This results in the crowding out of the non-NR-sector, which includes manufacturing ("direct de-industrialization"). This shift can cause a decline in the non-tradable sector's output.

Dutch disease can be a major problem if the development of non-NR tradable sectors, such as manufacturing, play a particular role in the industrialization process, for instance via spillovers (Sachs and Warner, 1995). For example, as Matsuyama (1992) suggested, if manufacturing is characterized by learning-by-doing, which means learning is proportional to total manufacturing production, a decline in a non-NR tradable sector can harm an economy's longer-term prospects. Studies find that in NR-rich countries manufacturing growth is slower, and the exchange rate subject to greater appreciation. Sachs and Warner (1999) show that among NR-dependent countries, on average, a 1\% increase in the share of NR exports in GNP in 1970 was associated with a $0.5 \%$ decrease in the share of manufacturing exports between 1970 and 1989. Egert (2012) finds clear signs of Dutch disease among the oil-producing, post-Soviet countries of Central and South-West Asia: an increase in oil prices resulted in an appreciation of their nominal and real exchange rates (though generally with a lag of one or two years). For other oil-exporting countries, during the period 1977 to 2004 Ismail (2010) finds that a 10\% increase in oil revenues is associated with a $3.4 \%$ fall in value added across manufacturing sectors, but he argues that manufacturing sectors are less affected by revenue shocks than their peers if they are more open to capital markets and foreign investment and have higher capital intensity.

\subsection{Volatility in the terms of trade}

Volatility in the terms of trade (the ratio of an index of a country's export prices to an index of its import prices) can harm an economy because unpredictable prices can lower the efficiency of economic activities. More specifically, volatility in the terms of trade causes cyclical shifts of labor, capital, and land across different sectors, which, by generating higher transaction costs, makes the whole economy less productive (Frankel, 2012). Commodity prices tend to be especially volatile because of the low short-run elasticity of supply and 
demand. When facing unexpected bad harvests or unwelcome weather, consumers find it difficult to adjust demand in response to lower supply. Prices will then rise to in order to clear the market (Frankel, 2012).

Empirical studies suggest that price volatility can adversely affect the economy by increasing macroeconomic fluctuations. Ploeg and Poelhekke (2009), for instance, show that from 1970 to 2003 the standard deviation of yearly GDP per capita growth is negatively correlated with GDP per capita growth; a 1\% increase in the standard deviation of the share of exports in GDP is on average associated with a $9.5 \%$ increase in the volatility of output growth. Considering the fact that commodity prices directly affect the share of exports in GDP, they suggest that these findings imply that the volatility of the commodity price appears to be the key feature of the natural resource curse. For commodities such as copper, bananas, coffee, and tobacco, Ploeg and Poelhekk (2007) draw the same conclusions. They also indicate that undeveloped financial institutions, ethnic tensions, and restrictions on the current account are likely to increase macroeconomic volatility, leading to lower growth. In commodity-exporting countries, moreover, the real price of commodity exports affects real exchange rate volatility (Cashin et al, 2004). Gylfason (2004) argues that the volatility of the exchange rate reduces trade and Foreign Direct Investment (FDI) in the non-NR sector, resulting in the shrinking of this sector. Real exchange rate volatility also exacerbates the negative effect of the undeveloped domestic credit market on economic growth (Aghion et al, 2009).

\subsection{Governance and institutions}

In addition to direct macro-economic effects, studies suggest that the presence of NR revenues can worsen overall governance by exacerbating corruption, political divisions, civil conflicts, and social unrest. This has long-term consequences for growth prospects. Where control of state institutions provides access to NR-rents actors have greater incentives to capture state machinery, by any means necessary, in order to enjoy the spoils. Indeed, the ODI finds that the share of income derived from the export of primary commodities is a powerful predictor of civil conflict (Overseas Development Institute, 2006). Where societies are already divided along ethnic or sectarian lines, competition for natural resources can exacerbate tensions over revenue allocations.

Empirical observations also suggest that large NR endowments lower institutional quality. By addressing the endogeneity of institutional quality, Sala-i-Martin and Subramanian (2003) suggest that dependence on oil and minerals has a seriously detrimental impact on long-run 
growth by lowering the quality of domestic institutions. They show that a one-point increase in the share of oil, gas, and mineral exports in GDP is on average associated with a $2.4 \%$ decrease in the Rule of Law index.

Lower quality governance also makes it harder to address the other NR-related macroeconomic challenges. Brahmbhatt, Canuto \& Vostroknutova (2010) argue that countries with poor governance are more likely to mismanage resources leading to unproductive rent-seeking activity and to mismanage macroeconomic challenges related to the volatility of primary commodity prices and structural changes such as Dutch disease. Rent seeking activities can lead governments to allocate revenues to less productive industries (Tornell and Lane, 1999). According to Gylfason (2001), governments and citizens with high income from NR have little incentive to educate people as they do not need to foster a productive economy in order to receive revenues. This lack of human capital in turn exacerbates government ineffectiveness.

If a government foresees a high level of future NR revenues it may borrow and overspend incurring debt which is unpayable if prices subsequently fall. Overspending or borrowing can also raise interest rates, and exchange rates (Countiho, 2011). Countiho (2011) also suggests that pro-cyclical fiscal policies can exacerbate real exchange rate volatility, which leads to poor economic performance. The absence of developed financial institutions will also make it harder to manage macroeconomic volatility (Ploeg and Poelhekke, 2009). Finally, Collier and Goderis (2007) show that countries with bad governance suffer from a significant long-run adverse effect of higher non-agricultural commodity prices; while those with good governance enjoy a significant positive effect. 
Figure 1: Relationship between natural resources and economic growth ${ }^{2}$

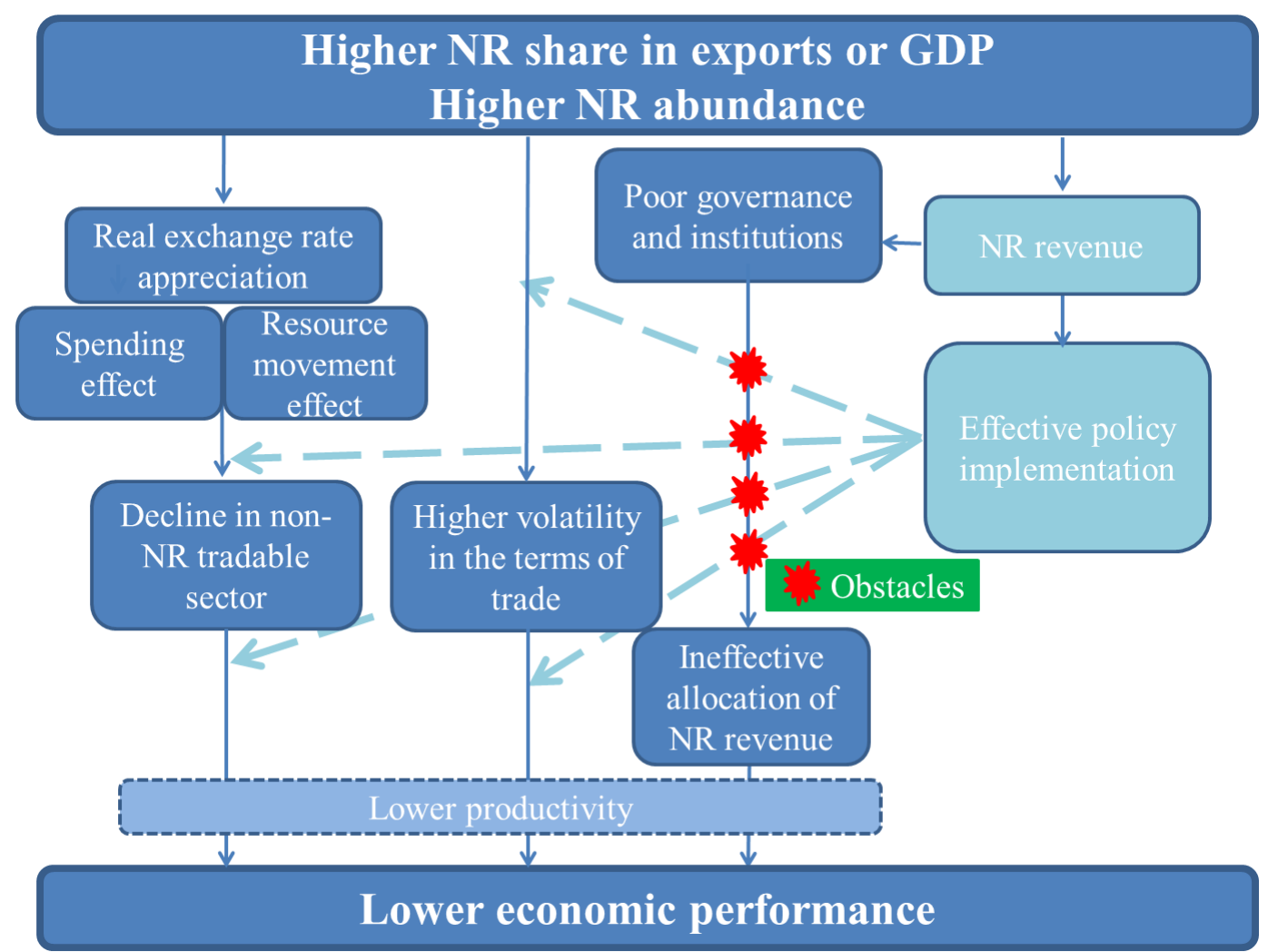

Source: Authors' elaboration based on the theoretical literature.

\footnotetext{
${ }^{2}$ Lower economic performance is defined as a sustained reduction of GDP growth of a country over a certain period of time. Many studies based on cross-country analysis look at the GDP growth rate from 1965 to the early-2000s. Literature based on panel data considers the effects of natural resource dependence on the level of GDP per capita, controlling for time-invariant country-specific characteristics. Note that not all of the studies observed a negative effect of natural resource dependence on economic performance: some observed a positive effect (e.g., Collier and Goderis, 2007; Alexeev and Conrad, 2009; Canuto and Cavallari, 2012).
} 


\section{Country analysis: Papua New Guinea}

\subsection{Overview}

Located on the eastern half of the island of New Guinea, in the southwestern Pacific Ocean, PNG has more than seven million inhabitants, and is the most populated island in the Pacific sub region. It is characterized by having substantial natural and mineral wealth and one of the most culturally diverse populations in the world. Since its independence from Australia in 1975, PNG has had a constitutional monarchy with a Prime Minister holding extensive executive power and a national parliament formed of 109 representatives elected every 5 years.

The country is divided into 20 provinces with a central government located in Port Moresby. The high levels of cultural diversity make it a very fragmented society with little sense of nationhood (Elek, n.d.). For example, the country's numerous ethnic groups or "clans" speak many different dialects, which creates tension and makes cooperation in the national interest difficult. Social fragmentation in PNG often leads to conflict. These tensions stem not only from unequal distribution of the benefits of growth and undemocratic decision-making processes, but also from concerns over the power and politics of resource use and control (Banks, 2008). Despite this, PNG has been able to maintain democracy at the national level. This paradox can be explained by the fact that no fragmented ethnic group is ever likely to have sufficient support to gain complete political control (Reilly, 2008).

PNG faces significant development challenges. Classified by the World Bank as a low-middle income economy, with a GDP per capita of US\$2,570, social well-being is very low, particularly given the large natural assets per capita ratio. For instance, life expectancy is only around 63 years. Approximately $87.5 \%$ of the population lives in rural areas. According to the Human Development Index (UNDP, 2012), in 2012, out of 186 nations, PNG ranked 156th in terms of the level of human development, below the level that would correlate with its GDP ranking. The ADB has calculated that, by $2009,28 \%$ of the population was living below the national poverty line. PNG is also very unequal. The available data shows that PNG had a GINI coefficient of 50.9 in 1996 - higher than present day China.

The census taken in the year 2000 reported an unemployment rate of $2.8 \%$ of the total labor force. However, the International Labor Organization (2008) warns that this statistic does not 
reflect the fact that the great majority of the population is engaged in the informal sector or in subsistence agriculture. Education levels also remain low: the mean years of schooling of the population is 3.9. This is 0.3 years less than the average of countries with low human development and 3.3 years less than the average of countries in East Asia and the Pacific region (UNDP, 2012). However, over the past five years, there has been an increase of $60 \%$ in adult literacy in the country

\subsection{Recent economic performance}

Since independence, the country has tried to take advantage of its abundant natural resources to foster economic growth, with sporadic success. Growth immediately after independence was slow, according to Elek (n.d.), and government budgets were largely financed by foreign aid. Local production increased only slowly and revenues were dependent on copper extraction (Chowdhury, 2004). With the aim of diversifying sources of revenue, the government turned its attention towards the export of mineral and agricultural commodities. By the end of the 1980s, several mining projects had started operations, which provided an increase in economic activity.

The 1990s was a decade of high economic volatility. Government revenues suffered when Bougainville Copper Limited (BCL), the biggest producer of copper in the country, closed following civil unrest. However, oil discoveries in 1992 and an increase in revenue from other copper mines (World Bank, 2010) helped PNG to improve its economic record. But this performance was not sustained. Excessive government expenditure, public borrowing, and inflation, resulted in the devaluation and eventual floating of the kina. Further macroeconomic mismanagement caused PNG's economic performance to deteriorate until the early 2000s (World Bank, 2010). 
Figure 2: Real GDP growth in Papua New Guinea (1995-2011)

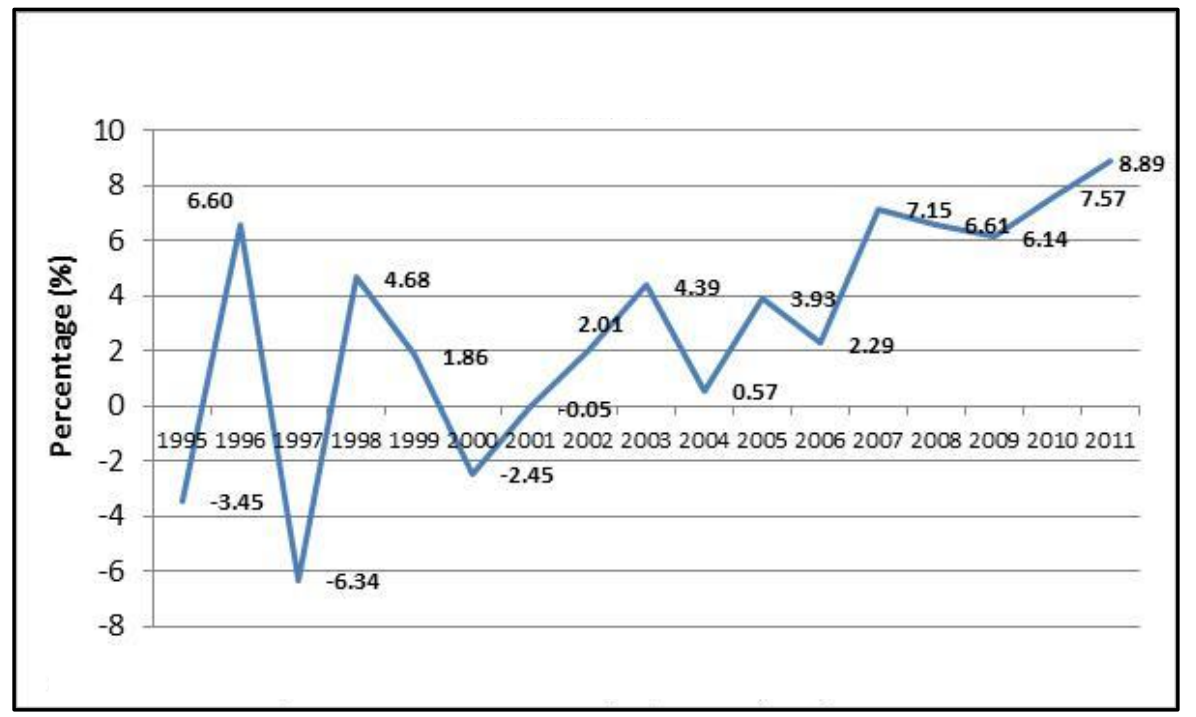

Source: ADB and PNG's Treasury Department (2012).

However, since 2007, PNG's economic performance has been quite strong, with real GDP growing at an average rate of $7.3 \%$ over the past five years (Figure 2 ). This is $4.5 \%$ above the average growth rate of other islands in the Pacific and comparable to the growth rate experienced by India in the same period. A great part of this performance can be attributed to strong demand for PNG's natural resource exports and increases in commodity prices (UNESCAP, 2011).

According to Baker (2011), growth in East and South Asia has boosted demand for the raw materials and other commodities that PNG produces. This strong demand has been combined with speculative forces and supply restraints in major producing areas resulting in high global commodity prices in recent years.

In terms of GDP composition, the evidence on sector growth is mixed (Figure 3). On the one hand, the agricultural sector has seen stable trends with slight fluctuations in its contribution to the economy. Currently, this sector represents around one-third of GDP (though the statistics may not account well for aggregate subsistence agricultural production) (Chowdhury, 2004). On the other hand, the industrial sector, which includes construction, provision of utilities, manufacturing, and mining, has had steady growth over the past two decades. It currently comprises $43 \%$ of PNG's GDP. This growth can be attributed to a continuing rise in the mining sector share, particularly the focus on the extraction of copper, gold, and oil (Chowdhury, 2004). 
Figure 3: Sectoral composition of GDP in Papua New Guinea at current prices

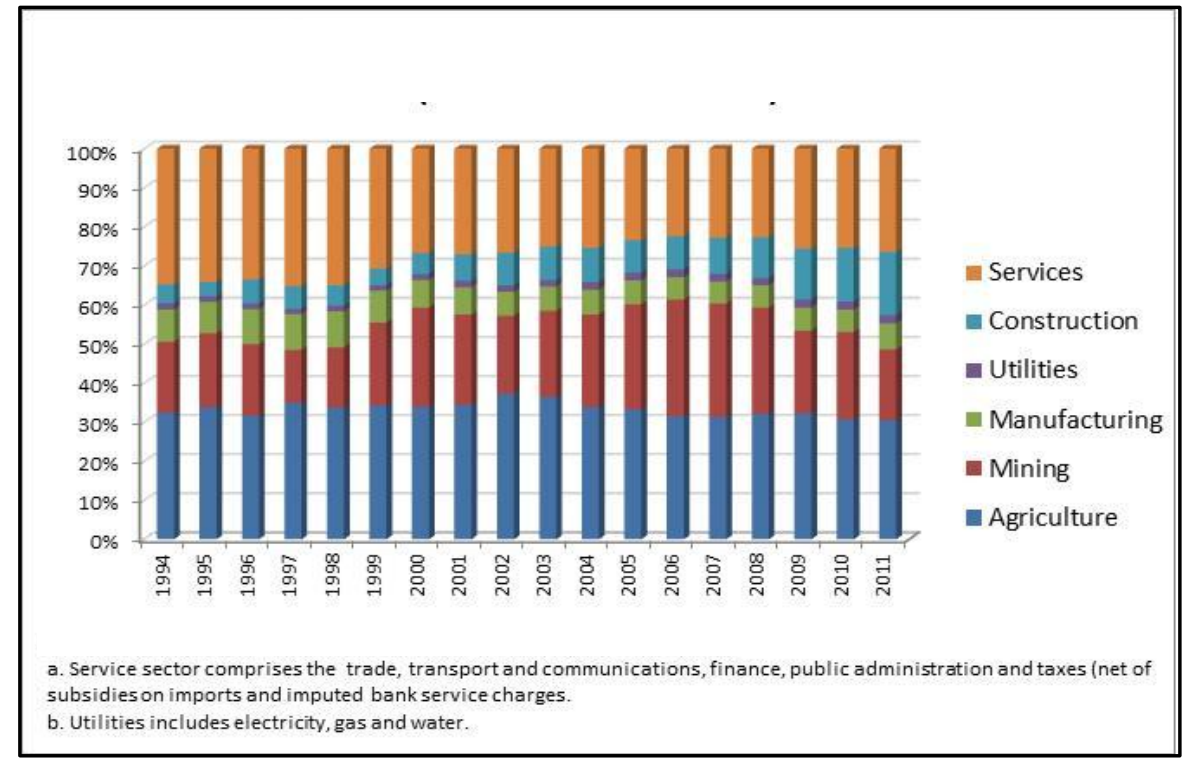

Source: ADB and PNG's Treasury Department (2012).

The rise of the construction sector is primarily a consequence of development of mining and oil facilities (World Bank, 2010). Foreign direct investment into mining projects has been a considerable source of economic growth since the 1990s. Expansion projects and the continuing inflow of investment in the 2000s have followed from the discovery of new natural resource reserves and improving extraction methods (World Bank, 2010). This sector is expected to expand in coming years with the exploitation of recently discovered natural gas reserves.

But the manufacturing sector has lost ground, with total output declining by almost 3\% over the past decade. The sector's share of GDP has also shrunk. The lack of skilled workers remains an obstacle facing companies. At the same time, the high costs of imported inputs and lack of public infrastructure are constraints on fostering profitable businesses.

The economy of PNG is highly dependant on foreign trade. Since the 1990s, the percentage of GDP corresponding to merchandise exports has been above $40 \%$. Starting in the 2000 s, this share increased to more than $50 \%$, reaching almost $80 \%$ of GDP in the mid-2000s. This increase is due in large part to an improvement in the terms of trade, the result of the mineral commodities price boom (World Bank, 2010). In 2008, the global financial crisis caused a reduction in the level of PNG's exported goods, adversely affecting for a short time the prices of mineral commodities and the economic capacity of some of PNG's main trading partners such as Japan, Spain, and Germany. 
Figure 4: Papua New Guinea's exports and imports (\% of GDP) (1994-2011)

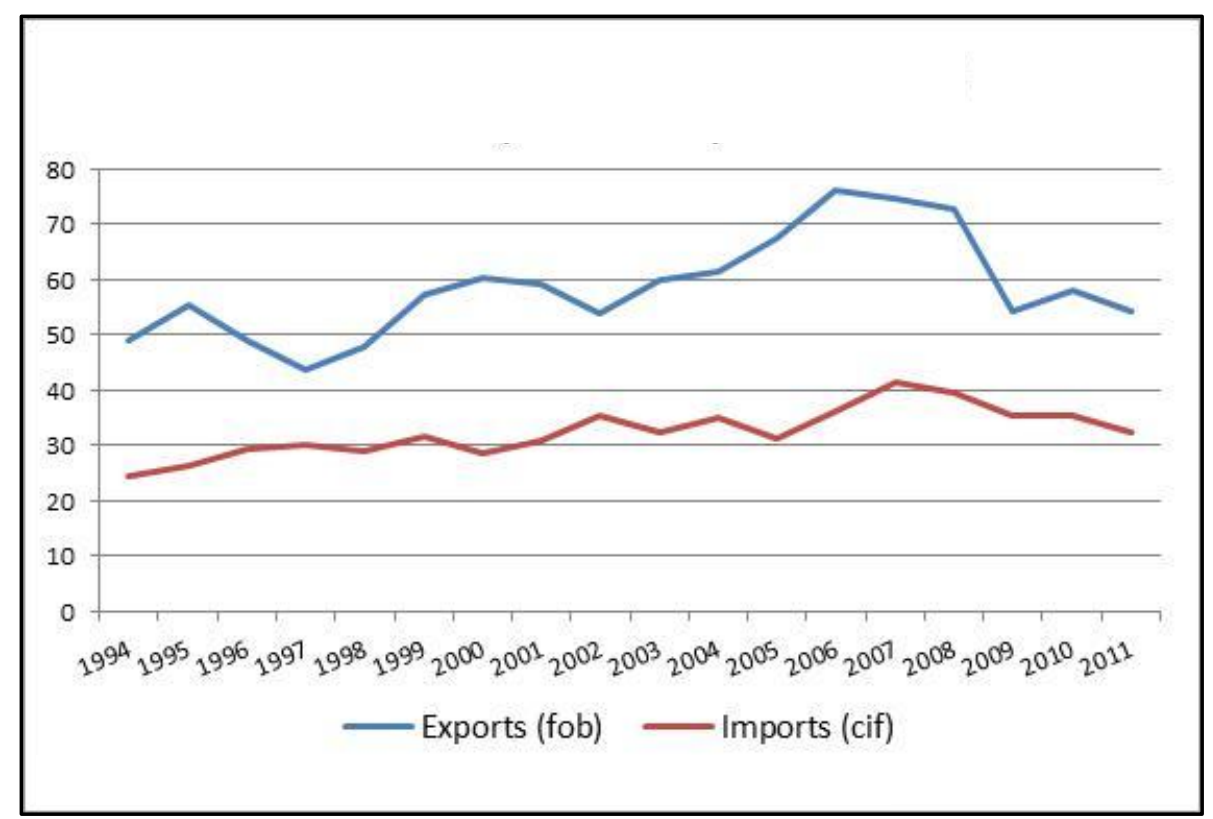

Source: ADB and PNG's Treasury Department (2012).

Despite the slowdown, merchandise exports as a percentage of GDP still remained above $50 \%$ (Figure 4). This is 20 percentage points above the average for low-income and low-middle income countries, whose average share of exports to GDP is around 30\%; as well as the average for other developing economies in East Asia and the Pacific region, whose average share is close to $38 \%$. Australia is PNG's main trading partner and accounted for $47 \%$ of PNG's total exports. Strong growth in Australia has helped sustain exports throughout the global economic crisis (Bank of Papua New Guinea, 2013).

As seen in Table 1, PNG has run current account deficits during the past three years. This is partly due to the rise in imports of construction materials for the LNG Project and large negative balances in compensation due to the compensation of foreign workers (IMF, 2012). According to the IMF (2012), PNG authorities have agreed that the current account balance will remain negative at least until the construction of the LNG project is finalized in 2014. At that point, it is expected that the balance will improve.

The servicing of external debt is also contributing to the balance of payments deficit. Table 1 shows that debt levels fell sharply from almost $66 \%$ of their GDP to reach less than $20 \%$ of GDP in 2009. This is explained by better fiscal management. However, in 2011 debt as a percentage of GDP increased sharply to $60 \%$ because of an increase in the level of external 
private non-guaranteed debt. The IMF (2012) explains that the LNG project is drawing on foreign private loans to be able to finance the construction.

The most recent report of the IMF (2012) argues that PNG's economy is still highly vulnerable to fluctuations in commodity prices. This is particularly important with regards to the annual budget and the composition of public spending. Lower commodity prices could reduce the revenues available to PNG's government and lead to an increase of the recently reduced public debt. While fiscal prudence was exercised during the 2004-2008 commodity boom (World Bank, 2010) recent deficits raise concerns about future expenditure management.

Recent years have seen the exchange rate strengthen against the dollar, in part because of capital inflows associated with the LNG project (UNESCAP, 2011). Inflation has fluctuated but remained below $15 \%$ in the past decade. Recent inflation is attributed to a rise in food and commodity prices and increasing domestic demand associated with the LNG project. Unless managed, rising inflation in PNG and the dependence on natural resource exports may threaten growth (UNESCAP, 2011). As we explain in upcoming sections, PNG's economic growth through is threatened by Dutch disease, volatility in the terms of trade, and weak governance. The most recent growth projections forsee a slowdown in PNG in future years (Howes, 2013). 
Table 1: Papua New Guinea's budget structure

\begin{tabular}{|c|c|c|c|c|c|c|c|c|c|c|c|c|}
\hline & 2000 & 2001 & 2002 & 2003 & 2004 & 2005 & 2006 & 2007 & 2008 & 2009 & 2010 & 2011 \\
\hline \multicolumn{13}{|c|}{ (in millions of Kinas, current prices, unless otherwise stated) } \\
\hline Budget Balance & -192.3 & -355.3 & -446 & -124.3 & 222.6 & 13 & 544.2 & 454.2 & -478.5 & -35.9 & 186.3 & -63.7 \\
\hline Total revenues & 2502.1 & 2465.8 & 2540 & 2957.1 & 3499.9 & 4043.6 & 5396.9 & 6307.6 & 6071.3 & 5773.8 & 6887.8 & 8279.9 \\
\hline Tax revenue & 2314.9 & 2294.3 & 2370 & 2677.9 & 3220.1 & 3744 & 4944.8 & 5854 & 5756.1 & 4974.5 & 6434.7 & 7904.2 \\
\hline Total expenditures & 3203.4 & 3544.2 & 3682 & 3784 & 4137.4 & 5316.4 & 5771.5 & 6556.5 & 7554 & 6690.5 & 8093.8 & 9395.7 \\
\hline Total (external) debt outstanding and disbursed & 2292.4 & 2037.1 & 1857.6 & 1866.5 & 1784.3 & 1880.2 & 1826 & 1430.5 & 1417.5 & 1572.8 & 5822.2 & n.d. \\
\hline $\begin{array}{l}\text { Current Account Balance } \\
\text { (millions of US\$ nominal) }\end{array}$ & 351.9 & 271 & -128.6 & 140.5 & 122.2 & 608.4 & 443 & 185.6 & 795.6 & .586 .1 & -648.4 & -48 \\
\hline FDI net inflows (millions of US\$, nominal) & -235.1 & & 19 & 104.9 & 25.7 & 27.1 & -7.9 & 88.1 & -30.4 & 419.8 & 28.7 & -311.5 \\
\hline Inflation & 15.6 & 9.3 & 11.8 & 14.7 & 2.1 & 1.8 & 2.4 & 0.9 & 10.8 & 6.9 & 6 & 8.5 \\
\hline Nominal exchange rates (kina per US\$) & 2.782 & 3.389 & 3.895 & 3.563 & 3.223 & 3.102 & 3.057 & 2.965 & 2.7 & 2.755 & 2.719 & 2.371 \\
\hline \multicolumn{13}{|c|}{ (as a percentage of GDP) } \\
\hline Budget Balance & -2 & -3.4 & -3.8 & -0.9 & 1.7 & 0.1 & 3.2 & 2.4 & -2.2 & -0.2 & 0.7 & -0.2 \\
\hline Total revenues & 25.7 & 23.7 & 21.4 & 22.3 & 26 & 26.8 & 31.9 & 33.4 & 28.1 & 25.9 & 26.1 & 27.7 \\
\hline Tax revenue & 23.8 & 22.1 & 20 & 20.2 & 23.9 & 24.8 & 29.3 & 31.1 & 26.6 & 22.3 & 24.4 & 26.5 \\
\hline Total expenditures & 32.9 & 34.1 & 31 & 28.6 & 30.7 & 35.2 & 34.2 & 34.8 & 35 & 30 & 30.7 & 31.5 \\
\hline Total (external) debt outstanding and disbursed & 65.5 & 66.4 & 60.9 & 50.2 & 42.7 & 38.6 & 33.0 & 22.6 & 17.7 & 19.4 & 60.0 & n.d. \\
\hline $\begin{array}{l}\text { Current Account Balance } \\
\text { (millions of US\$ nominal) }\end{array}$ & 10.1 & 8.8 & -4.2 & 3.8 & 2.9 & 12.5 & 8.0 & 2.9 & 9.9 & .7 .2 & -6.7 & -0.4 \\
\hline FDI net inflows (millions of US\$, nominal) & -6.7 & 0.0 & 0.6 & 2.8 & 0.6 & 0.6 & -0.1 & 1.4 & -0.4 & 5.2 & 0.3 & -2.5 \\
\hline
\end{tabular}

Source: Asian Development Bank and PNG's Treasury Department (2012). 


\subsection{Role of natural resources in the Papua New Guinea economy}

PNG is richly endowed with natural and mineral resources, and produces a wide range of primary commodities including crude oil, natural gas, timber, cocoa, coffee, palm oil, gold, copper, silver, nickel, and cobalt. Exports are almost totally comprised of commodities, with minerals, oil and gas making up around $70 \%$ of exports by value and agricultural products the next largest sector at around 20\% (Bank of PNG, 2013).

With respect to agricultural products, coffee and palm oil are especially prominent with a contribution of $23 \%$ and $31 \%$, of total agriculture exports respectively (Table 2 ). Crude oil extraction reached its peak in 1993; however, there has been a decline in activity due to natural resource depletion (PNG MTDP, 2010). The Bank of PNG reported an average of 27,000 barrels of crude oil exported per year over the past decade.

Mineral extraction has played an important role in the national economy since at least 1970. The mining industry has also been growing in recent years thanks to the increase in commodity prices, relatively efficient corporate management of the sector, and a more stable macroeconomic environment. Gold mining has dominated the mining sector with Porgera (Enga Province) and Lihir (New Ireland Province) as the two largest gold mines. In 2009 and 2010, two more mines started production: the Hidden Valley gold and silver mine (Morobe Province) and the Ramu nickel-cobalt mine. For the period 2001-2011, exports of minerals accounted for an average of $76 \%$ of total exports (Table 3 ). Within mineral exports, gold exports accounted for $45 \%$ of the total over the same period, followed by crude oil (32\%) and copper (22\%). In 2005, mineral export receipts accounted for $49.7 \%$ of GDP.

According to the Mineral Resources Authority of Papua New Guinea, mining activity between 1970 and 2007 produced 5 million tons of copper. The Ok Tedi Mine, an open-pit copper and gold mine located in the Star Mountains Rural LLG of the North Fly District of the Western Province of PNG, has been the most active mine in terms of copper production. The mine, operated by Ok Tedi Mining Limited (OTML), is majority owned by the PNG Sustainable Development Program Limited (Ok Tedi Mining, 2013). 
Table 2: Agriculture and other non-mineral exports classified by commodity (\% of agriculture exports)

\begin{tabular}{|c|c|c|c|c|c|c|c|c|c|c|c|}
\hline & 2001 & 2002 & 2003 & 2004 & 2005 & 2006 & 2007 & 2008 & 2009 & 2010 & 2011 \\
\hline Cocoa & $15 \%$ & $21 \%$ & $19 \%$ & $13 \%$ & $10 \%$ & $12 \%$ & $12 \%$ & $12 \%$ & $15 \%$ & $12 \%$ & $10 \%$ \\
\hline Coffee & $31 \%$ & $25 \%$ & $21 \%$ & $17 \%$ & $24 \%$ & $20 \%$ & $18 \%$ & $18 \%$ & $21 \%$ & $18 \%$ & $28 \%$ \\
\hline Tea & $3 \%$ & $2 \%$ & $1 \%$ & $1 \%$ & $1 \%$ & $1 \%$ & $1 \%$ & $1 \%$ & $1 \%$ & $1 \%$ & $0 \%$ \\
\hline Copra & $1 \%$ & $1 \%$ & $0 \%$ & $1 \%$ & $1 \%$ & $1 \%$ & $0 \%$ & $2 \%$ & $1 \%$ & $1 \%$ & $2 \%$ \\
\hline Copra Oil & $2 \%$ & $3 \%$ & $5 \%$ & $5 \%$ & $5 \%$ & $4 \%$ & $5 \%$ & $7 \%$ & $4 \%$ & $4 \%$ & $5 \%$ \\
\hline Palm Oil & $30 \%$ & $36 \%$ & $30 \%$ & $26 \%$ & $20 \%$ & $26 \%$ & $29 \%$ & $34 \%$ & $32 \%$ & $35 \%$ & $45 \%$ \\
\hline Rubber & $1 \%$ & $1 \%$ & $1 \%$ & $1 \%$ & $1 \%$ & $1 \%$ & $1 \%$ & $1 \%$ & $1 \%$ & $1 \%$ & $1 \%$ \\
\hline Refined Petroleum & - & - & - & $12 \%$ & $25 \%$ & $16 \%$ & $22 \%$ & $17 \%$ & $17 \%$ & $21 \%$ & $0 \%$ \\
\hline Others & $17 \%$ & $11 \%$ & $22 \%$ & $24 \%$ & $12 \%$ & $18 \%$ & $11 \%$ & $9 \%$ & $9 \%$ & $8 \%$ & $9 \%$ \\
\hline $\begin{array}{l}\text { AGRICULTURE EXPORTS } \\
\text { (\% total exports) }\end{array}$ & $13 \%$ & $17 \%$ & $18 \%$ & $20 \%$ & $19 \%$ & $13 \%$ & $16 \%$ & $19 \%$ & $19 \%$ & $19 \%$ & $23 \%$ \\
\hline
\end{tabular}

Source: Bank of Papua New Guinea (2013).

Table 3: Mineral exports classified by commodity (\% of mineral exports)

\begin{tabular}{cccccccccccc}
\hline & 2001 & 2002 & 2003 & 2004 & 2005 & 2006 & 2007 & 2008 & 2009 & 2010 & 2011 \\
\hline Crude 0il & $0 \%$ & $0 \%$ & $22 \%$ & $46 \%$ & $39 \%$ & $34 \%$ & $48 \%$ & $46 \%$ & $33 \%$ & $39 \%$ & $42 \%$ \\
Gold & $52 \%$ & $66 \%$ & $54 \%$ & $39 \%$ & $39 \%$ & $34 \%$ & $34 \%$ & $39 \%$ & $50 \%$ & $44 \%$ & $44 \%$ \\
Copper & $46 \%$ & $32 \%$ & $23 \%$ & $14 \%$ & $21 \%$ & $31 \%$ & $17 \%$ & $14 \%$ & $16 \%$ & $16 \%$ & $13 \%$ \\
0thers\% & $2 \%$ & $1 \%$ & $1 \%$ & $1 \%$ & $1 \%$ & $1 \%$ & $0 \%$ & $0 \%$ & $1 \%$ & $1 \%$ & $1 \%$ \\
\hline $\begin{array}{c}\text { MINERALEXPORTS } \\
\text { (\% total exports) }\end{array}$ & $80 \%$ & $75 \%$ & $75 \%$ & $71 \%$ & $74 \%$ & $82 \%$ & $78 \%$ & $76 \%$ & $76 \%$ & $76 \%$ & $71 \%$ \\
\hline
\end{tabular}

Source: Bank of Papua New Guinea (2013) *Includes silver, alluvial gold and others. 
Under current plans, the Ok Tedi Mine was to close around the end of 2013. However, the OTML management is in the process of undertaking a Feasibility Study to extend mine life as an alternative to closure, with the extension comprising a combination of underground and open pit mining. The Mine Life Extension (MLE) is expected to produce an estimated total of 90 million tons of ore containing almost 700,000 tons of copper and 2.3 million ounces of gold. The MLE production rate is expected to be about $60 \%$ of the current production rate (OK Tedi Mining, 2013).

The importance of commodities is increasingly reflected in their share of total employment. Although the percentage of employment in the mining and petroleum industry is relatively low compared to other sectors, such as agriculture, the number of people employed in the mineral industry has risen in recent years (Table 4). PNG Chamber of Mines and Petroleum reports that direct employment in the mining and petroleum industry - including project employees, contractors, and exploration - is currently estimated to be over 30,000 . According to OTML, the Ok Tedi Mine employs about 2,000 people, 95\% of them PNG citizens.

Table 4: Total labour force, agriculture labour force, and change in mineral labour index ${ }^{3}$

\begin{tabular}{|c|c|c|c|}
\hline Year & $\begin{array}{c}\text { All sectors } \\
\text { (thousands) }\end{array}$ & $\begin{array}{c}\text { Agriculture } \\
\text { (thousands) }\end{array}$ & $\begin{array}{c}\text { Mineral (\% } \\
\text { change) }\end{array}$ \\
\hline 2001 & 2386 & 1764 & $-6 \%$ \\
2002 & 2457 & 1793 & $2 \%$ \\
2003 & 2526 & 1819 & $-1 \%$ \\
2004 & 2596 & 1854 & $-2 \%$ \\
2005 & 2666 & 1895 & $6 \%$ \\
2006 & 2740 & 1934 & $10 \%$ \\
2007 & 2807 & 1978 & $16 \%$ \\
2008 & 2875 & 2021 & $7 \%$ \\
2009 & 2950 & 2065 & $3 \%$ \\
2010 & 3025 & 2110 & $6 \%$ \\
2011 & 3107 & 2155 & $8 \%$ \\
\hline
\end{tabular}

Source: Bank of Papua New Guinea and UNCTAD (2013).

One of the most significant developments in PNG in recent years has been the discovery and development of large Liquefied Natural Gas (LNG) fields. PNG's newest LNG project is likely to become the biggest single investment in the country. The LNG project is operated by Esso Highlands Limited, a subsidiary of ExxonMobil, and is located in the Southern Highlands and Western Provinces (The PNG LNG Project, 2013). The project has a capacity of 6.6 million tons per year and over 9 trillion cubic feet of gas. Two hundred million barrels of associated

\footnotetext{
3 The Bank of PNG collects quarterly data on the formal private sector employment index from its Business Liaison Survey (BLS) which covers enterprises with 20 or more employees in the main centers of the country.
} 
liquids are expected to be produced over the life of the project. Although construction began in 2010, the first LNG shipment is scheduled for 2014, providing a long-term supply to companies in Taiwan, Japan and China (Chamber of Mines and Petroleum (b), 2013). According to the International Monetary Fund (IMF), more than 14,300 workers are employed by the LNG project, $60 \%$ of them PNG nationals.

The project's construction costs (US $\$ 15.7$ billion) are being financed by a mix of equity and debt $(30 \%$ and $70 \%$, respectively). The largest private sector equity participants are ExxonMobil affiliates (33.2\%) and Oil Search Limited (29\%), which also has exploration activities in Yemen, Iraq, and Tunisia (Oil Search Limited, 2013). The PNG government owns a $16.8 \%$ stake, mostly through the Independent Public Business Corporation, and landowners own $2.8 \%$. The government also owns shares amounting to $15 \%$ of Oil Search (IMF, 2012). Production costs will include goods imports and payments to foreign workers, projected at about US $\$ 1$ billion annually. The expected operational life of the project is 30 years (IMF, 2012).

Esso Highlands also plans additional future phases of the LNG project. Other plants such as Hides, Angore, and Juha will undergo improvements and new wells in 2019, 2017-18, and 2021-22, respectively. InterOil plans to develop the Elk and Antelope gas fields, with an annual production of 7.6-10.6 million tons. Talisman Energy found gas reserves at exploratory wells in 2010 and will spend US\$800 million on further exploration over 2012-15.

The importance of the LNG project to the local economy is considerable. The IMF (2012) projects that real GDP will rise by about $20 \%$ when LNG production reaches full capacity in 2015, although GNI will rise by less because of dividend outflows. Thereafter, annual GDP growth is projected to average around $5 \%$.

Thus, taking into account the rents coming from PNG's main natural and mineral resources (Figure 5), we observe that the country experienced a decline in 2007, but it is increasing in recent years due to the development of the LNG project and increases in commodity prices (Figure 6). The World Bank (2012) defines NR rents as the total sum of oil, natural gas, coal (hard and soft), minerals, and forests. ${ }^{4}$ In other words, this is the sum of the differences between the value of the production of each natural resource at world prices and their total costs of production.

\footnotetext{
4 The World Bank includes in this category minerals such as tin, gold, lead, zinc, iron, copper, nickel, silver, bauxite, and phosphate.
} 
Figure 5: Natural resource rents in Papua New Guinea (\% of GDP) (1990-2010)

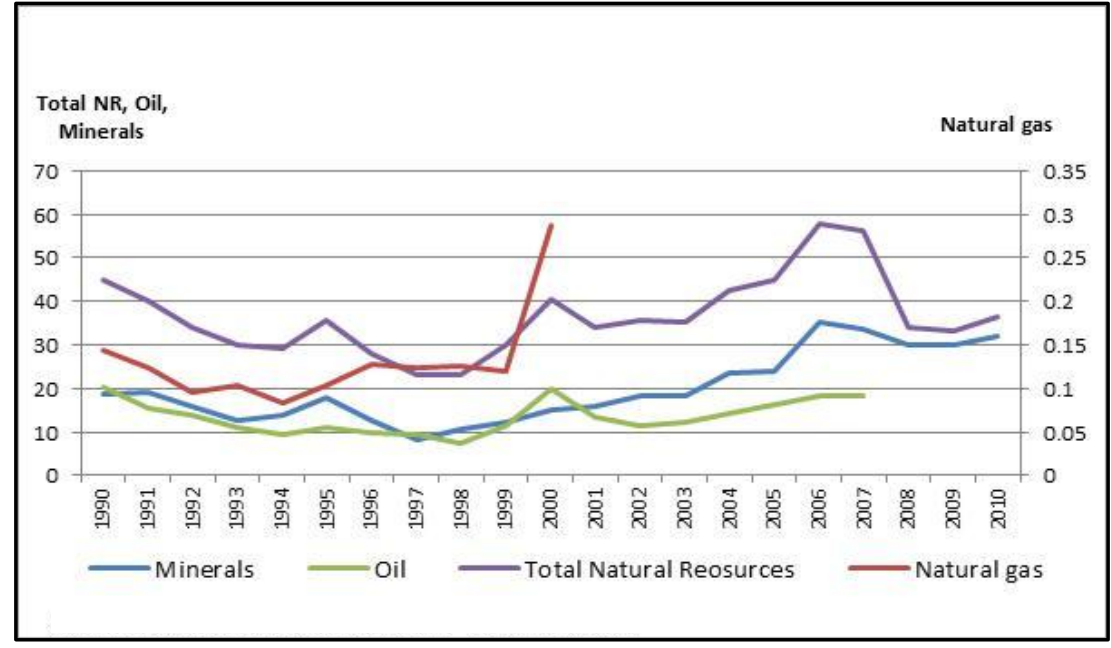

Source: World Development Indicators - World Bank (2012).

A great part of the earnings from extractive industries, however, flows offshore to service debt and reward shareholders (Elek, n.d). In the period 1996-2000, the government of PNG raised royalties from $1.25 \%$ to $2 \%$ and imposed a $4 \%$ mining levy on assessable mining income, which, according to the World Bank (2006), negatively affected the country's competitiveness and made PNG less attractive to FDI. Beginning in the early 2000s, tax provisions applying to the oil, gas and mining industry went through a major reform designed to stimulate investment activity (PWC, 2013). The government eliminated the additional profit tax, and reduced the dividend withholding tax to $10 \%$. The royalty rate was also fixed at $2 \%$ of net smelter returns. Today, mining and petroleum companies are subject to different rates of taxation. For instance, resident mining and gas companies pay a corporate tax of $30 \%$ of gross profits which is the same rate as non-NR companies. However, non-resident mining and gas companies pay rates that go from $30 \%$ to $50 \%$ depending on when they began their operations. In 2008, the 10\% levy for mining companies was eliminated (World Bank, 2010), and the Additional Profit Tax for gas companies (which was eliminated during the early-2000s reform) was reinstalled when the definition of "designated gas project" changed. As a result of these changes, PNG became more attractive to foreign investors. In 2003, it was ranked fourth among 24 countries in terms of estimated rate of return for a model copper mine.

Some commentators have questioned whether PNG receives a sufficient share of the benefits from natural resources (Kuwimb, 2010). Kuwimb explains that colonial laws effectively divested indigenous peoples of their ownership and property rights of natural resources. After independence, however, these laws were changed. For example, according to section 5 (1) of PNG's Mining Act (1992), nowadays "all minerals existing on, in or below 
the surface of any land in PNG, including any minerals contained in any water lying on any land in Papua New Guinea, are the property of the State." Similarly, section 6 (1) of PNG's Oil and Gas Act (1998) establishes that: "notwithstanding anything contained in any other law or in any grant, instrument of title or other document, all petroleum and helium at or below the surface of any land is, and shall be deemed at all times to have been, the property of the State." Indigenous landowners in areas affected by minerals projects receive royalties from the operations.

Figure 6: Export prices (\% change)

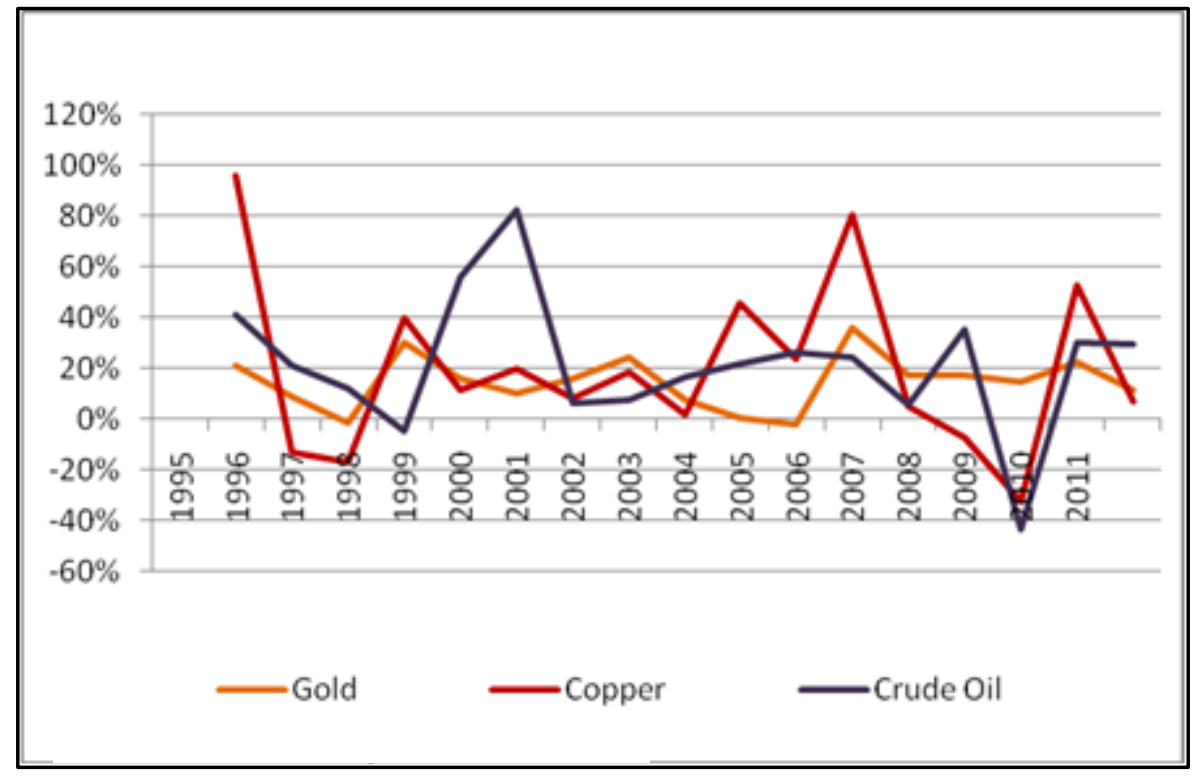

Source: Bank of PNG.

The legal framework governing investment in natural resource activities in PNG states that a foreign enterprise must first obtain a certification from the Investment Promotion Authority (IPA). In turn, the 1992 Investment Promotion Act guarantees the protection of certain activities related to investment for the certified enterprises, such as protection against nationalization or expropriation and an entitlement of remittance overseas at a prevailing exchange rate. In terms of environmental protection, the 2000 Environment Act and the 1992 Mining Act also affect FDI decisions. Under the 2000 Environment Act, for example, enterprises that implement projects of national importance or that may cause serious environmental harm, must apply for an environmental permit with the Department of Environment and Conservation (DEC). ${ }^{5}$ The 1992 Mining Act stipulates that an applicant of a

\footnotetext{
${ }^{5}$ Sections 41 and 42 of PNG's 2000 Environmental Act.
} 
mining lease must submit a proposal with measures that will help to adequately protect the environment. The proposal must be approved by the Mining Advisory Board. ${ }^{6}$

But in terms of revenues, the government of PNG depends heavily on income taxes with mining and petroleum taxes providing only around 15\% of revenue. Although in 2012 the non-tax revenue increased more than the tax revenue (34.7\% and $3.3 \%$ respectively), the latter accounted for $80.4 \%$ of total revenue that year (Department of Treasury, 2013). This percentage was driven by collections of tax on income and profits, domestic taxes on goods and services, and taxes on international trade (Figure 7). The first category represented $73.1 \%$ of total tax revenue and includes personal income tax, company tax, mining and petroleum, and dividend withholding, among others. The Mining and Petroleum Tax alone represented $13.9 \%$ of total tax revenue. International trade, company and dividend withholding tax may also affect natural resource companies, accounting for a total of $47.2 \%$ approximately.

Figure 7: Papua New Guinea's tax revenue structure (\% of total revenue) (2012)

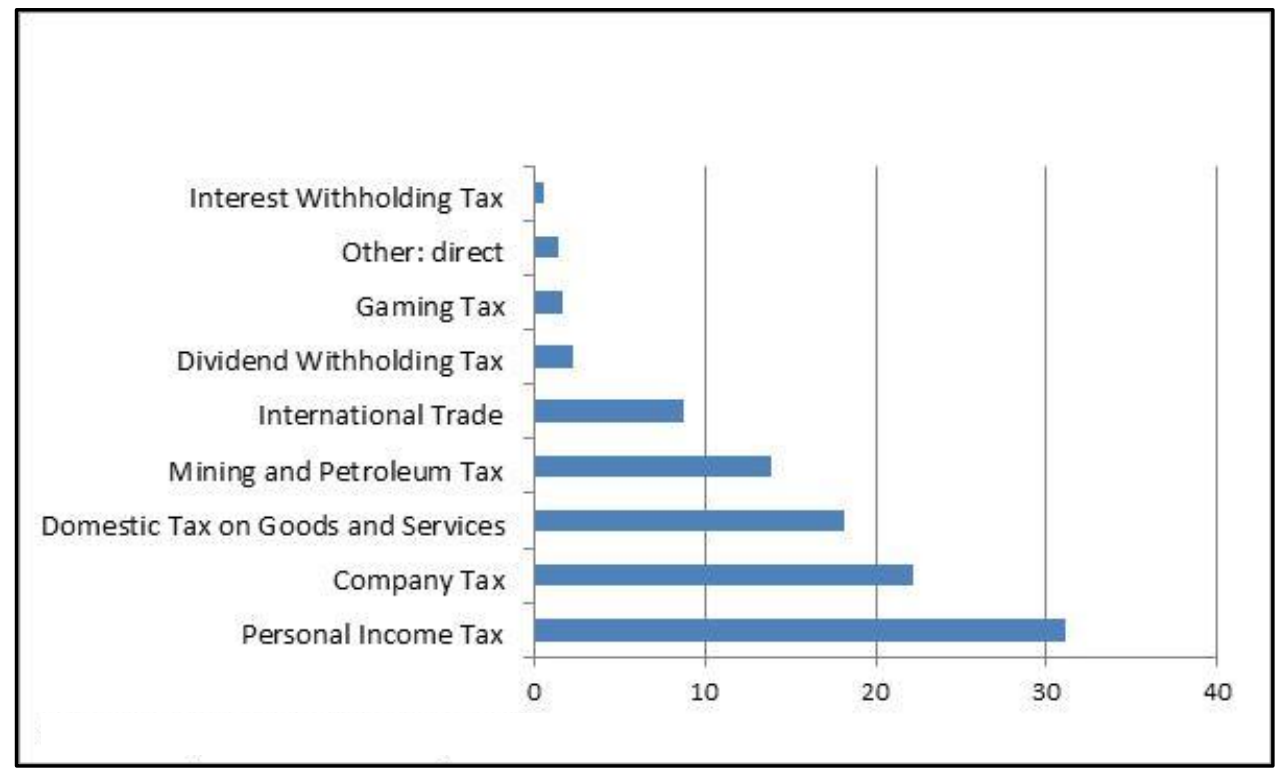

Source: Department of Treasury (2013).

In their 2013 budget, the Treasury Department of PNG indicated that tax revenues are not expected to increase as significantly in the near future due to the deceleration of the global economy. However, projections from the IMF (2012) detailed that fiscal revenues from the LNG project will begin in 2018 and peak in 2024. By 2024, LNG-related government revenues are projected to grow to around $10 \%$ of non-mineral GDP, as extended depreciation

\footnotetext{
${ }^{6}$ Section 43 (1) (a) (ii) of PNG's 1992 Mining Act.
} 
allowances are used up. Despite this projection, the IMF (2012) has also highlighted the importance for the government and its people to receive an appropriate share of profits from NR activities if they want to maintain PNG's economic performance.

\subsection{Evidence that Papua New Guinea is affected by the natural resource curse}

Having surveyed the national economy, the importance of the natural resource sector is striking. It is therefore important to consider the extent to which PNG has experienced any of the symptoms of the 'curse'. Below we consider the evidence related to each of the transmission channels outlined in section I.

\subsubsection{Dutch disease}

PNG arguably first experienced symptoms of Dutch disease during the 1971-1977 investment and mineral boom (Chowdhury, 2004). The government responded to the boom by increasing current expenditure through wages and salaries, and the acquisition of goods and services. Formal employment in the mining sector grew in comparison to private non-mining employment, confirming a labor shift from the non-NR sector to the NR-tradable sector. By 1974, the contribution of mining to GDP was $25 \%$. However, by the end of 1974 , commodity prices started to decline.

The implementation of prudent macroeconomic policies and good fiscal management in the second half of the 1970s allowed PNG to cope with the impact of commodity price volatility. In contrast, during a second mineral boom in 1991 and 1993, undisciplined fiscal policies leading to a rising deficit worsened the symptoms of Dutch disease (Chowdhury, 2004). New petroleum discoveries and an increase in gold prices fueled economic growth and government expenditure, widening the fiscal deficit. The real exchange rate appreciated and external competitiveness declined. In October 1994, following large capital outflows and a rundown of foreign reserves to near zero, the government was essentially forced to switch to a flexible exchange rate regime and abolish wage indexation.

In the midst of a new natural resource boom fueled by an increase in commodity prices and the inflows of foreign investment with the LNG project, PNG is again experiencing fast economic growth. 
Figure 8 shows the relation between the real exchange rate and the contribution of the NR rents to GDP. There appears to be a lag between the appreciation of the real exchange rate and the increase in NR rents. For example, from 1990 to 2000, PNG experienced an increase in NR exports rising from $25 \%$ to $40 \%$ of GDP. This was accompanied by a real appreciation of the kina of approximately $9 \%$ in the subsequent period. We also find this in the period from 2004-2007, when the NR rents experienced a greater increase (from 35\% to 57\% of GDP) whereas the real exchange rate followed its regular trend. It was not until 2007 that the real exchange rate reacted to the increase in rents, appreciating approximately $35 \%$ between the years 2007-2011.

Investment in the LNG project and the increase in mineral commodities (particularly copper) could prolong the appreciation of the kina. A stronger kina could result in more difficult conditions for local manufacturers. For instance, plywood manufacturers are experiencing increasing competition from Chinese imports at lower prices (Price, 2012).

Figure 8: Papua New Guinea's real effective exchange rate and natural resource rents (1998-2011)

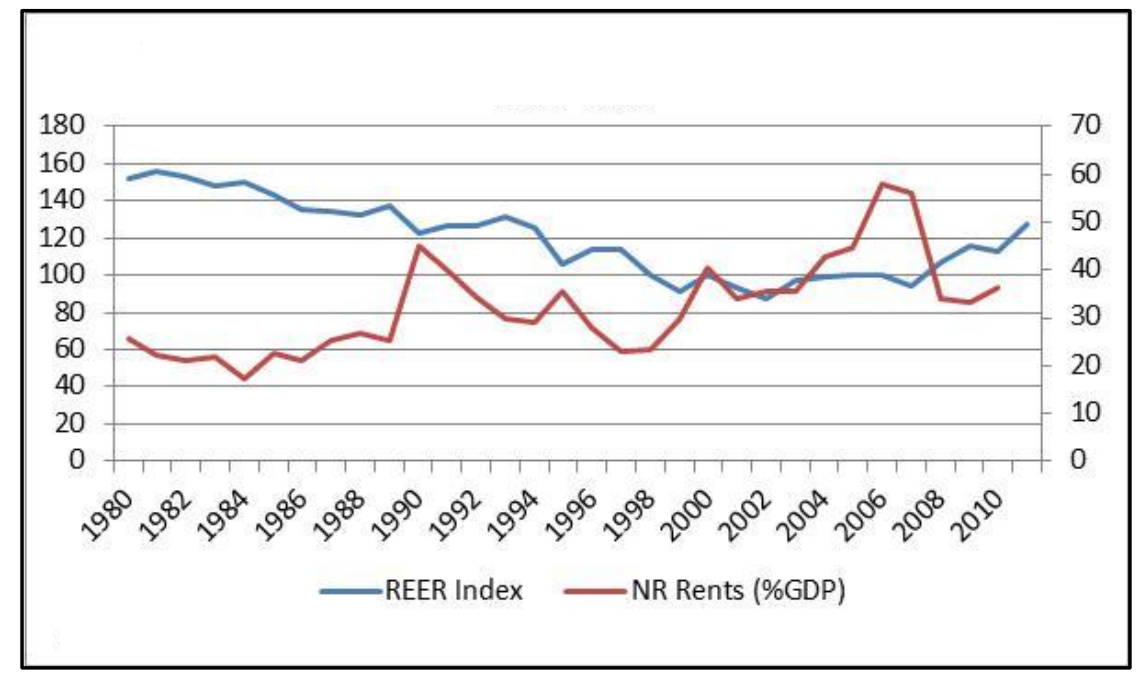

Source: World Development Indicators- World Bank (2012).

Competitiveness in PNG's manufacturing sector has been hindered by real exchange rate appreciation. The contribution of manufacturing to the economy started to decline in 1999 as the NR rents began to increase (Figure 9). In the past 10 years, PNG has experienced a $39 \%$ real appreciation of the kina, which has translated into a reduction of 3 percentage points of the manufacturing sector's share of GDP, from $8 \%$ of GDP to $5 \%$. Experts also warn about the effects of the appreciation of the kina in the agricultural sector, which supports more than $70 \%$ of the country's population. 
Figure 9: Papua New Guinea's manufacturing value added and Natural Resource rents (\% of GDP) (1980-2011)

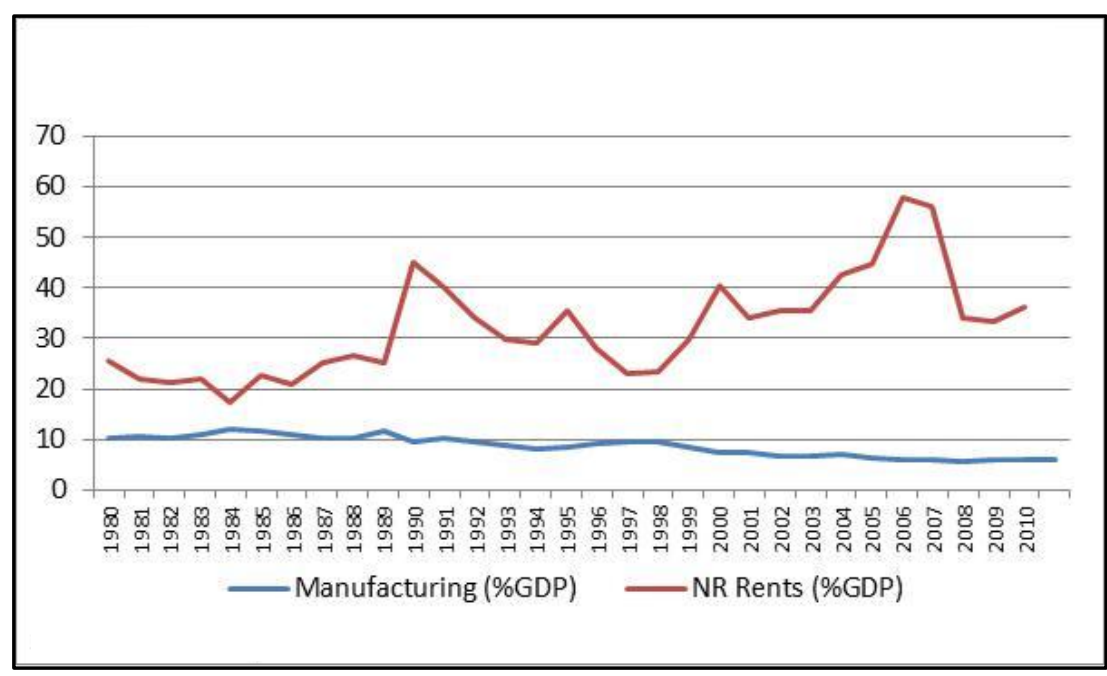

Source: World Development Indicators- World Bank (2012).

Although previous studies have not definitively confirmed that PNG suffers from Dutch disease (World Bank, 2010), more recent data could lead to the conclusion that PNG may experience renewed effects of Dutch disease in the medium-term, especially as LNG rising exports will put further upwards pressure on the Kina. The lag between the appreciation of the real exchange rate and the increase in NR rents, as well as the increase of LNG production in coming years, support this conclusion.

\subsubsection{Volatility in the terms of trade}

PNG has suffered from volatility in its terms of trade (TOT) as is typical in resource dependent economies. When looking at the variation in PNG's terms of trade (TOT) in the last decade (Figure 10), we observe pronounced changes, especially after 2006. This trend in PNG's TOT is consistent with the change of commodity prices in international markets. For instance, in 2009, PNG's TOT suffered a deterioration (Figure 10) associated with a decrease in the prices of commodities, especially crude oil and copper (Figure 6). One year later, in 2010, the increase in commodity prices (copper and crude oil, Figure 6) boosted PNG's TOT (Figure 11). Similarly, the increase in the price of copper and gold in 2006 (Figure 6), resulted in a big improvement in PNG's TOT in the same year (Figure 10). The current decrease in the TOT's growth rate (year 2011 in Figure 10) is possibly associated with an increase in the price of imports due to the LNG project's development. 
Given that the data available is limited to only 11 years, we are not able to discuss long-term volatility in PNG's TOT. However, the information available provides evidence of pronounced annual changes which, according to the theory presented earlier, may generate macroeconomic volatility, hampering the business climate in PNG.

The most recent natural resource curse literature generally argues that an appreciation of the TOT can increase the inflow of rents coming from natural resource activities which, in turn, may hamper economic growth. Volatility also imposes costs on businesses, making planning and investment harder. Since the year 2006, there has been a clear reduction in the net NR rents as a percentage of GDP which has been fallen alongside PNG's net barter TOT (Figure 12). In other words, there has been a reduction in the growth rates of the country's TOT that has resulted in a lower percentage of NR rents. A reduction in the TOT also has the potential of disincentivizing rent-seeking activities given the lower amount of NR rents in the country which could result in a better allocation of resources.

Figure 10: Papua New Guinea's net barter terms of trade and natural resource rents (2001-2011)

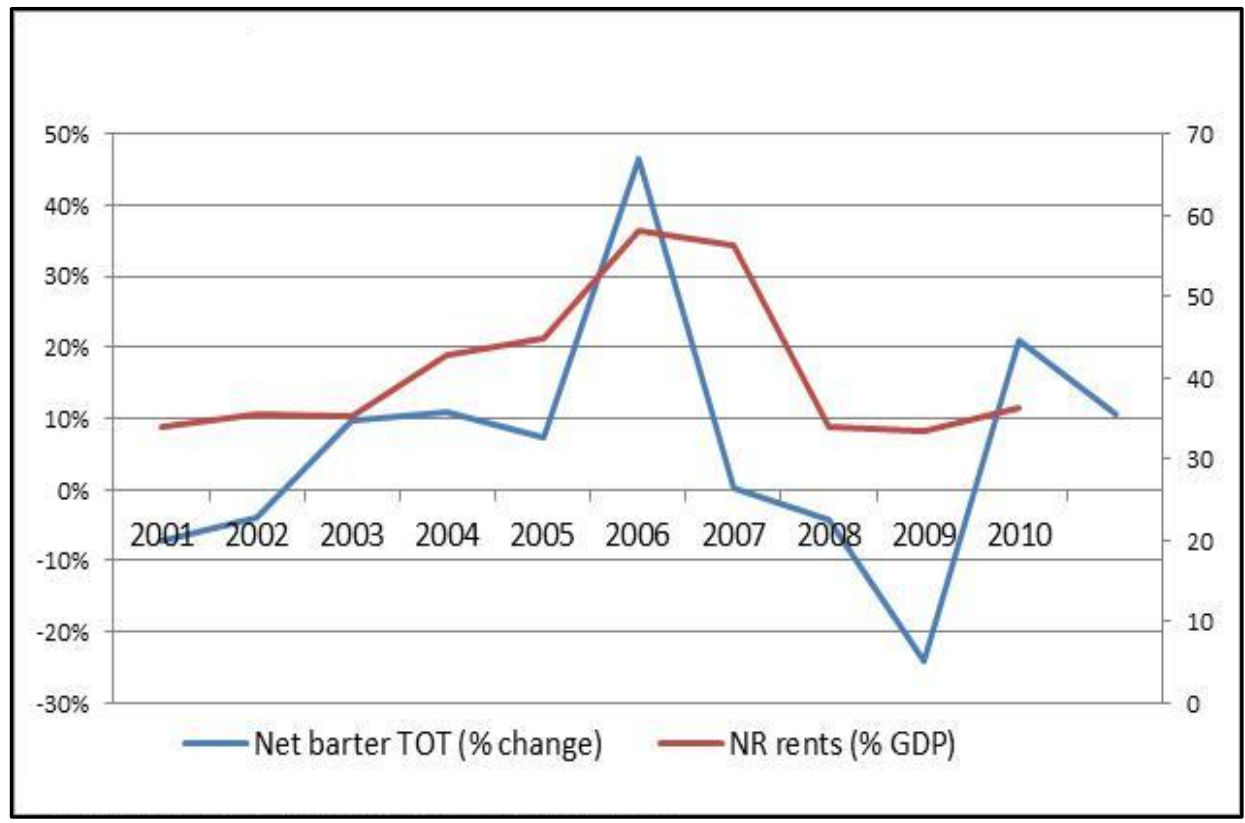

Source: World Development Indicators- World Bank (2012).

It is hard to observe any obvious connection between changes in the TOT and GDP growth (Figure 11). Despite the analysis made in this section, we therefore cannot conclude that the annual changes in TOT have presented a major challenge for PNG. However, the lack of data has been a limitation in determining the effect of TOT volatility in the economy which, as mentioned before, may have negative effects on the economy's productivity and the business 
climate of PNG. As mentioned by Fosu (2011), high TOT volatility can have an adverse impact on a country's economic performance, especially, if most of the government's revenues come from natural resource rents.

Figure 11: Papua New Guinea's net barter terms of trade and GDP growth (2001-2011)

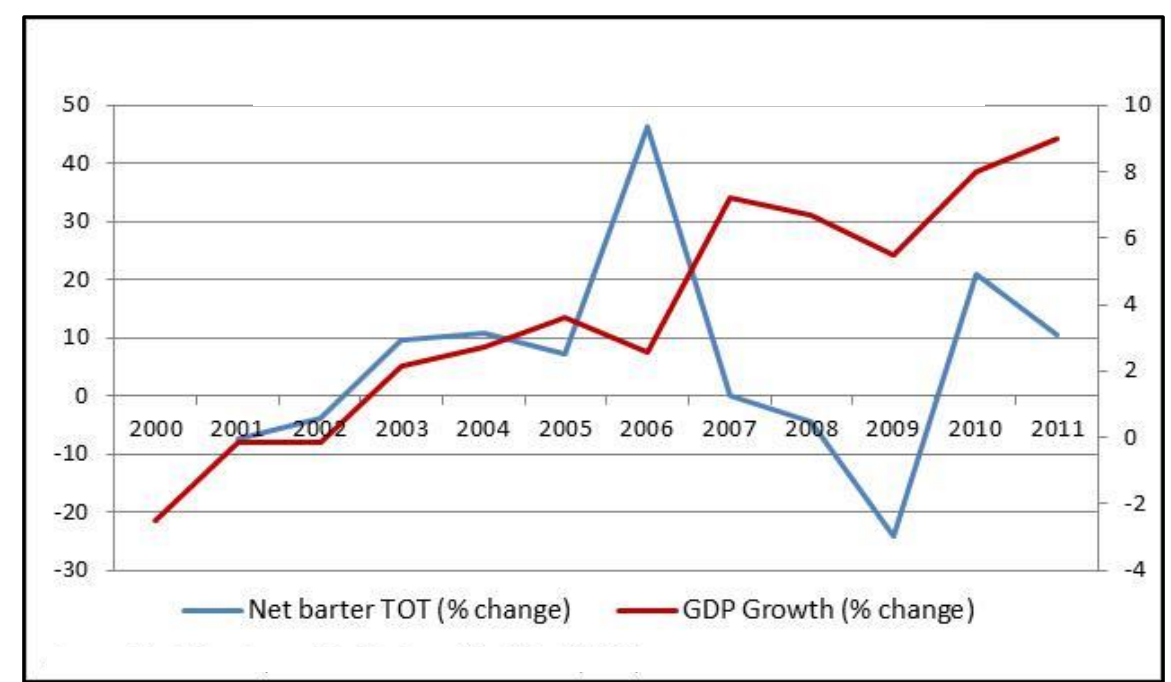

Source: World Development Indicators, World Bank (2012).

\subsubsection{Governance}

Natural resource rents may disincentivize the kinds of good governance and social policies that contribute to long-term sustainable growth. According to the World Bank's Governance Indicators (2012), institutional quality in PNG has not improved in the last 15 years (Figure 12). Particularly concerning are the low levels for the index of control of corruption.

Competition over access to resource rents may exacerbate inter-clan competition in politics. Clan behaviour can be explained by seeing clans as rival interest groups seeking to derive maximum benefits for their members via rent-seeking (Reilly, 2008). Macroeconomic uncertainties and external pressures in PNG have been accentuated by underperforming institutions that hinder proper policy implementation. Elek (n.d.) suggests that sustaining a government accountable to its citizens and committed to development is difficult when a high share of its revenue is generated from a few extractive-based projects. 


\section{Figure 12: Papua New Guinea's governance quality index (1996-2011)}

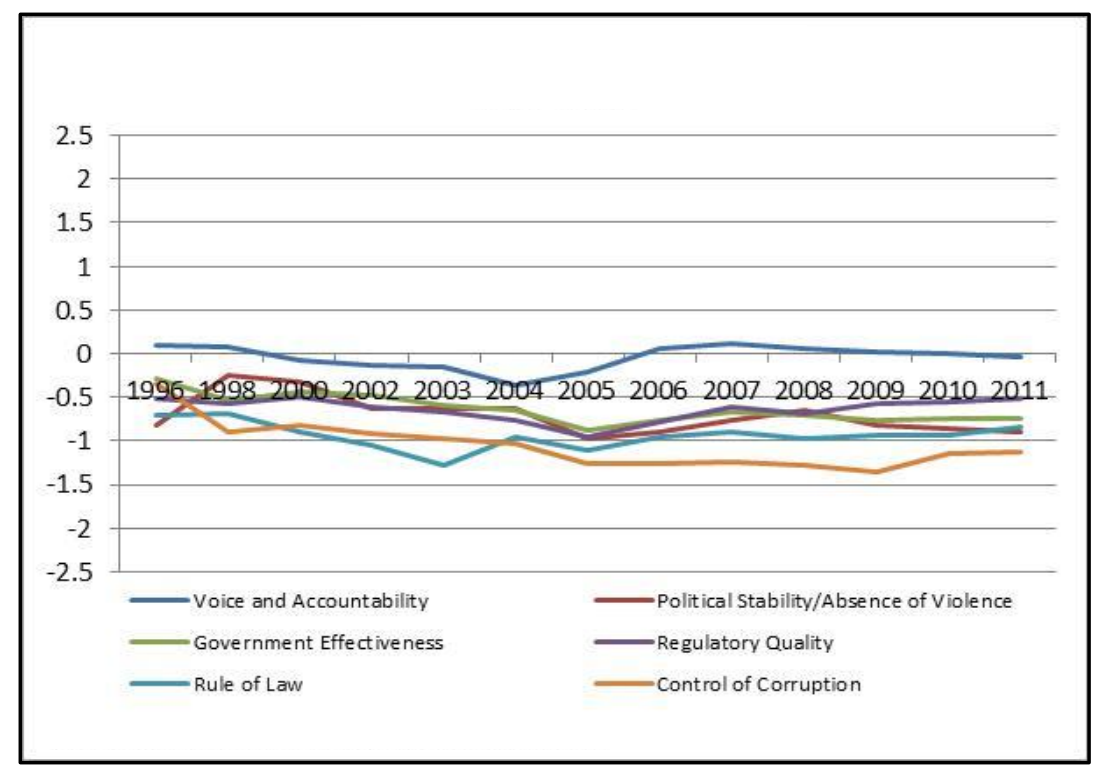

Source: World Governance Indicators- World Bank (2012).

Governance can be further damaged by the potentially corrosive impact of revenues coming from NR in terms of accountability, transparency, and government capability in the delivery of services (Morris, 2011). Politics in PNG is shaped by elites and politicians who have devoted resources to obtaining power and need resources to provided patronage benefits to clients in return for support. (Teskey, 2013). This undermines prospects for effective political authorities able to regulate rent management.

Using the World Governance Indicators (2012), we observe the negative relation between NR revenues and institutional factors including effectiveness and control of corruption (Figures13 and 14). The variable, NR rents as a percentage of GDP, is used as a proxy of the net revenue coming from natural resources. Compared to other countries, PNG has one of the highest ratios of NR rents to GDP. This has possibly reduced the ability of the government to control corruption (Elek, n.d.). 
Figure 13: Natural resource rents and control of corruption (PNG in red)

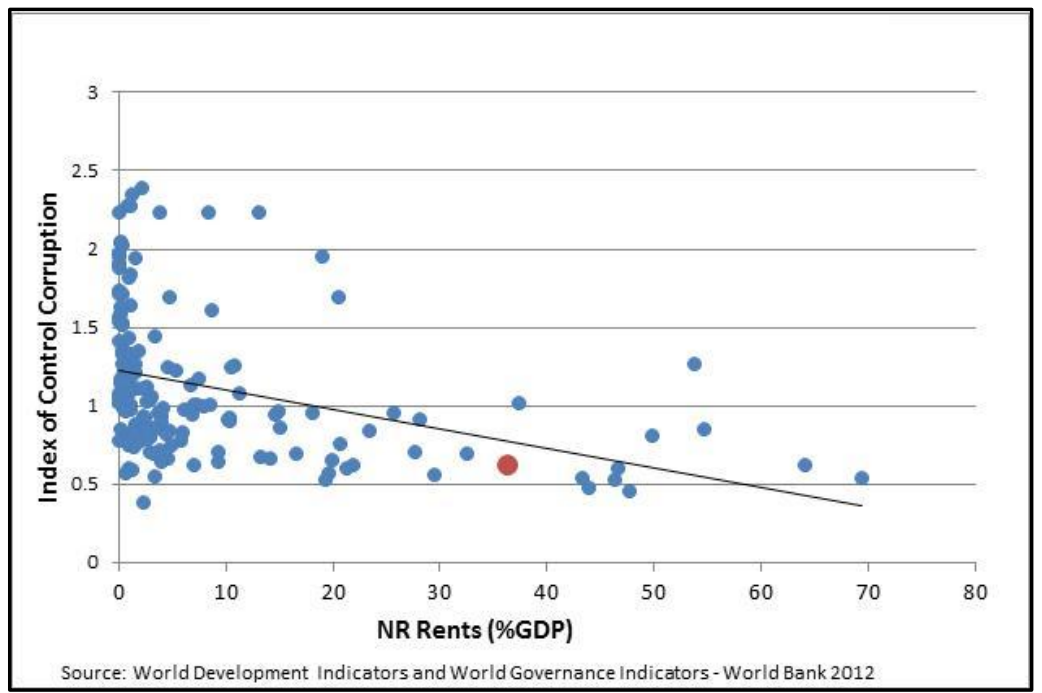

Source: World Development Indicators and World Governance Indicators- World Bank (2012).

Figure 14: Natural resource rents and government effectiveness (PNG in red)

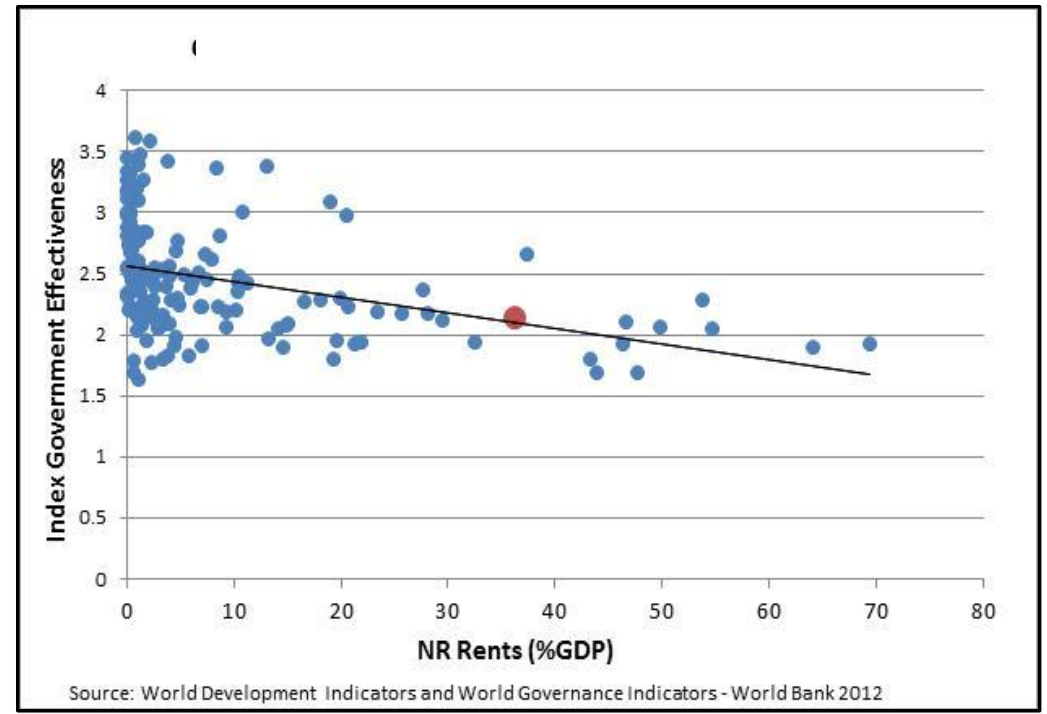

Source: World Development Indicators and World Governance Indicators- World Bank (2012).

A second challenge for PNG is how to effectively spend the revenues that flow from NR. For years, most of PNG's population, particularly those living in the highlands, has been unable to take advantage of opportunities deriving from natural resource booms (Barker, 2011). Currently, because of underperforming institutions, large inflows of revenue from the LNG project do not translate into social expenditure and investments in public infrastructure. The weak capacity of PNG's government agencies to deliver services and public goods to its citizens is a constraint on economic development. For example, producers of fruit, vegetables and sugar in rural areas that supply PNG's domestic markets cannot take advantage of the 
rising income of urban consumers due to impassable roads and inadequate infrastructure, which leads to spoiled goods, uncontrolled pests, and theft (Barker, 2011).

Figure 15: Natural resource rents and human development (PNG in red)

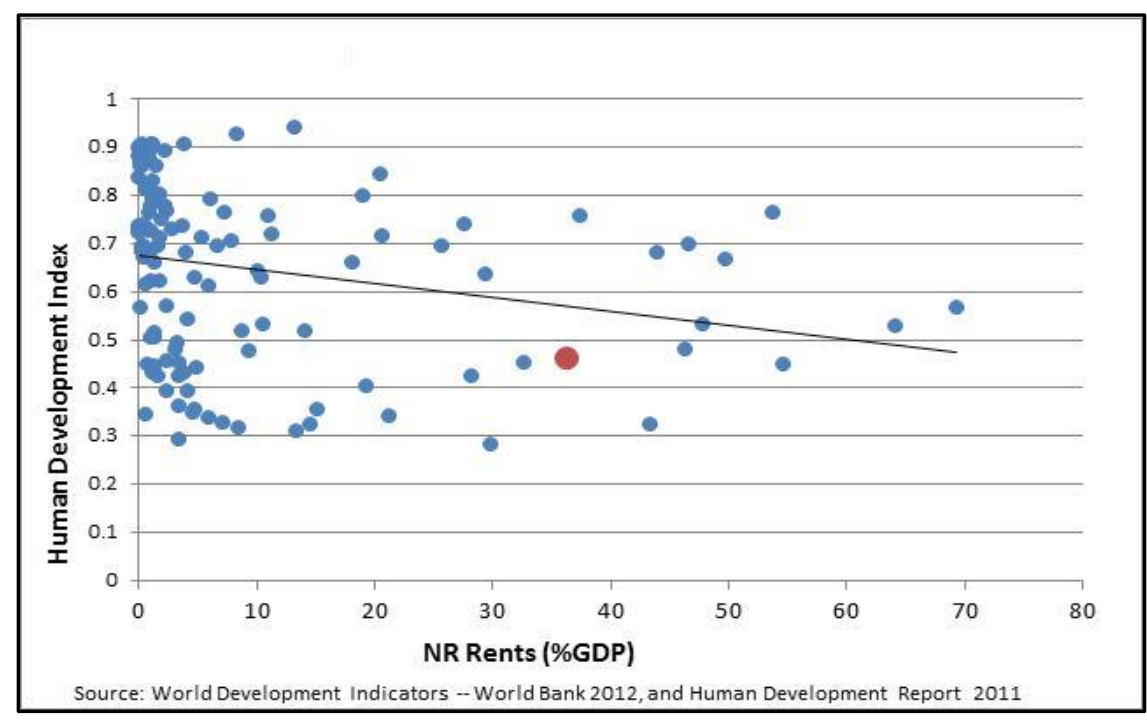

Source: World Development Indicators- World Bank (2012) and Human Development Report (2011).

Figure 16: Natural resource rents and GDP per capita (PNG in red)

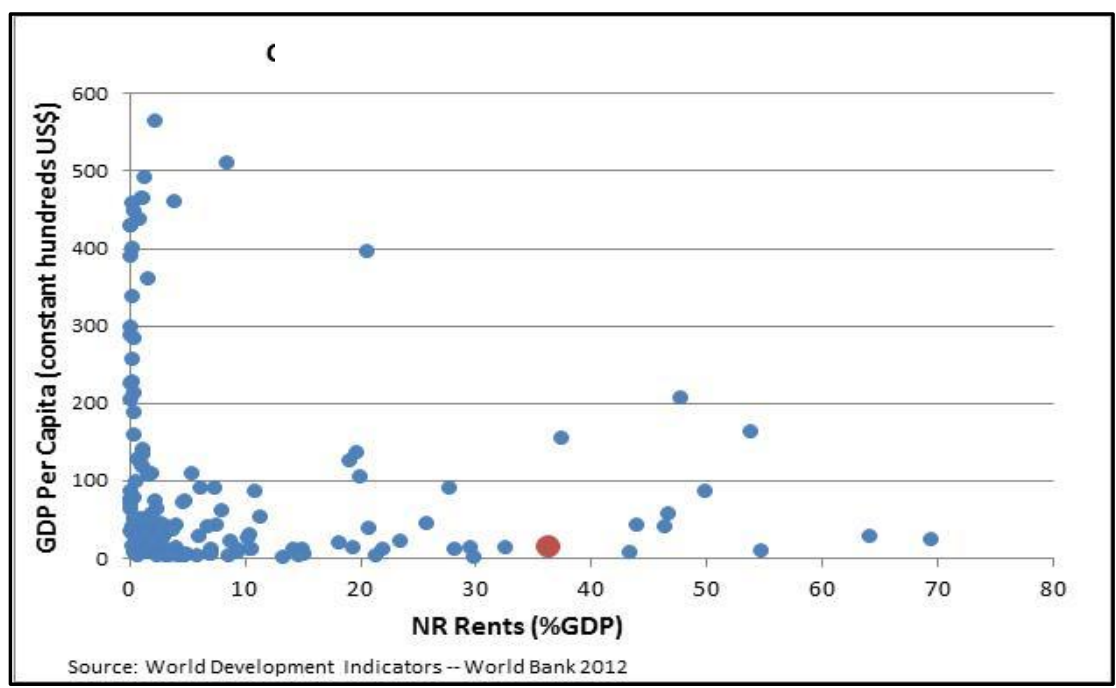

Source: World Development Indicators- World Bank (2012).

According to Figure 15, there is a negative relationship between NR rents and the Human Development Index (2012). In PNG, progress in delivering health and education and building quality infrastructure has been mostly left to mining and petroleum companies (Chand et al., 2000). According to the IMF (2012), this trend is expected to change in the coming years since the composition of public spending has been shifting towards prioritizing infrastructure 
projects and basic services. Furthermore, we observe evidence of lower GDP per capita relative to other countries, in spite of its abundant NR rents (Figure 16).

In conclusion, although PNG has grown strongly since 2007, there are challenges that threaten the country's future economic growth. One is the danger of Dutch disease and the decline of the non-NR tradable sector, especially manufacturing. A second challenge is how to deal with the volatility in the country's terms of trade, which negatively affects the productivity of the whole economy. A third challenge for the country is how to improve the relationship between the PNG government and the NR producing companies.

The biggest challenge for PNG, however, is related to weak governance and institutions, and the lack of control of corruption, which can affect the implementation of macroeconomic policies and development plans. Rent seeking activities, for instance, lead governments to allocate revenues to less productive industries, neglecting other important social sectors (such as education and infrastructure) that can improve social welfare. In this context, ineffective spending of NR revenues by the government can impede development. This is particularly true in the case of PNG, where it is difficult to regulate rent management, among other things, because elites and politicians are likely to benefit their supporters, taking advantage of weak regulations and low public accountability. 


\section{Policy Recommendations}

\subsection{Mitigating the damage from Dutch disease}

In order to mitigate the damage in the non-NR tradable sector (including manufacturing) as a result of Dutch disease, it is necessary to encourage effective public investments funded by NR revenues. ${ }^{7}$ These investments are not necessarily limited to supporting specific industries, but, more generally, infrastructure and education. ${ }^{8}$ By improving human capital and the business environment, PNG can become a more competitive location for manufacturing. One policy option to achieve this objective is to produce a long-term development (investment) plan for making better investments. Although a plan will not guarantee effective investment implementation, it could be a first step. Effective targeting of public spending will be particularly important. The Mongolian Human Development Fund is one successful example to consider. The spending from this fund is targeted towards the more vulnerable segments of the population, through investment in health, education, infrastructure, and productive capacity. By raising the living standards of the poorest, such public investments are expected to advance human development and help achieve long-term economic growth, even after the NR has been exhausted (Clark, 2011).

PNG has already established long-term development plans: Vision 2050, PNG Development Strategic Plan (2010-2030), and the PNG Medium Term Development Plan 2011-2015. In addition, PNG also has some rules in place about the areas where the government can spend NR revenues (Organic Law on the Sovereign Wealth Fund, Section 13; "SWF law" thereafter). ${ }^{9}$ Although PNG's long-term plans are criticized for not fully promoting prioritization in the application of the rule on NR revenue usage (for instance, it does not apply to all mineral and petroleum NR revenues), these policies should lead to better public investments to some extent. According to Batten (2012), PNG's 2013 National Budget increased the share of spending in health, education, transport infrastructure, and law and order from less than $20 \%$ in 2007 to $32 \%$. Funding for development to local governments was also increased in 2013. For example, PNG's government decided to pay all 2012 tuition fees

\footnotetext{
7 The production of NR in itself can provide opportunities to develop capabilities. For example, it can supply tools for NR extracting companies (Rielaender, 2013).

8 There is much discussion regarding the allocation of public investment. Even though the manufacturing sector is the first area to be considered for long-term development, a World Bank discussion note points out that their small size and distance from large markets limits the capacity of Pacific Island countries to follow the dominant path of economic growth, from agriculture to manufacturing (World Bank's Pacific Department 2011). Mr. Loi Martin Bakani, Governor of the Bank of Papua New Guinea, claims that PNG should invest on making agriculture more competitive given that it is a major source of income for a large share of the population (Bakani, 2012).

9 For more information, see the presentation by Anthony Yauieb, Deputy Secretary of Department of Treasury at PNG Budget Forum in 2012, available in http://devpolicy.anu.edu.au/png-budget-project/budget-fora/
} 
for all students attending preparatory school to grade 10 in registered and approved schools in the National Education System (Department of Education, 2012).

However, it is too early to conclude that PNG is making the necessary investments to has overcome the dangers of Dutch disease. PNG's weak governance and institutions (its biggest challenge) can hamper the effectiveness of public investment, even when a substantial amount of NR revenue is allocated to public goods.

\subsection{Offsetting the impact of commodity price volatility}

Because it is likely to remain primarily a resource-dependent economy, PNG will always be confronted by volatility in the terms of trade due to changes in primary commodity prices. In order to cope with this problem, effective fiscal and monetary policies are required. Fiscal policies can contribute to stabilizing the economy by setting aside NR revenues during high NR price periods to prepare for periods with lower NR revenues as a result of a decline in NR prices or after the point where NR extraction has hit its peak. Saving a part of the revenues generated during economic periods of higher NR prices will also work as a countercyclical macroeconomic policy measure.

One option for implementing this measure is to establish a fiscal rule to prevent excessive spending during high NR price periods. This would replace the current budget system, in which lawmakers annually debate the optimal spending level. Although there are many kinds of useful fiscal rules for stabilizing macroeconomic policy (e.g. setting limits on the primary non-NR balance, government expenditure, and debt), the most straightforward rule for stabilizing NR revenue expenditure is to set limits on the amount of NR revenue to be spent in each financial year. To make this rule successful, robust limits are desirable to mitigate the pressure from short-term spending needs. An excessively rigid or complicated sets of rules, however, might make the rule unsustainable (World Bank, 2010). Having independent panels of experts to forecast the long-run price of the commodity exports would be also beneficial. One successful example is Chile's fiscal rule, which saves all copper-related revenues in a Copper Stabilization Fund when the commodity price exceeds a certain threshold. These fiscal rules are often implemented by a Nonrenewable Resource Fund (NRF) to manage NR resources with transparency.

There is a wide array of international experience in establishing NRFs. Their purpose is not limited to stabilization and often includes other purposes such as savings for future 
generations and stabilizing currency movements. Examples of these funds include the Norwegian Petroleum Fund, and the State Oil Fund of the Republic of Azerbaijan (SOFAZ) among others. The World Bank (2010) and Overseas Development Institute (2006) provide good summary tables of NRFs.

Although PNG established a Sovereign Wealth Fund (SWF) in 2011, its effectiveness is yet to be evaluated. This fund is expected to stabilize PNG's economy, since PNG's SWF law explicitly stipulates that all NR revenues from mineral and petroleum and earnings from investments of NR revenues shall be incorporated into the fund (SWF law, Section 10). It also stipulates that the withdrawals from the stabilization fund shall not exceed the 15-year moving average of mineral and petroleum revenues as a share of non-mining revenue (SWF law, Section $11(1))$.

In order to prevent an overheated economy, monetary policy should also be countercyclical. Although discussing better monetary policy in a general context is beyond this paper's scope, in the context of NR management, Frankel (2012) advocates inflation targeting by product price instead of the Consumer Price Index (CPI).

Other policy options to address the volatility in the terms of trade include using financial contracts to hedge volatility, as Mexico has done (Blas, 2012). Frankel (2012) recommends indexing oil or mineral contracts to the world prices of the commodity, including clauses for automatic adjustment of the prices if world market conditions change in contracts with foreign purchasers.

\subsection{Building a better relationship with natural resource producing companies}

Like Kuwimb (2010), some commentators argue that the PNG government has little control over the country's NR and thus, only a small share in total NR revenues is allocated to promoting development in the nation. This problem can result in limited government capacity to prevent Dutch disease, which is more serious in NR-rich developing countries, like PNG, that must rely on foreign companies for NR-based development.

Stiglitz (2012) insists that governments have the right to appropriate a substantial amount of $N R$ revenues, and that they should maintain the option to renegotiate contracts with NR producing companies or impose taxes. Renegotiation is not easy, since government is bound 
by contract, and since renegotiation can harm the relationship with NR producing companies. To accomplish this, it is important to develop NR management regimes that are designed to be inclusive at the start.

In 1974, PNG successfully renegotiated a tax holiday on the benefits from the Bougainville mine (Garnaut and Ross, 1983). More recently, the PNG government's announcement of a review of the mining taxation is particularly welcome because there are suspicions that PNG's mineral projects are riddled with tax exemptions (Stephen, 2013). PNG should continue reviewing the terms of existing contracts with NR producing companies, and try to renegotiate them if needed. For instance, PNG could apply Mongolia's super profits tax, which is imposed when the market price of the NR exceeds a predetermined specified level, as discussed by Radon (2007).

When renegotiating a contract, the government needs to consider impacts on FDI. According to the United Nations (2011), there are two sets of factors that foreign investors seriously consider: 1) supply-side factors, including infrastructure, transportation, water and electricity (all of which are important to the mineral production process), and availability of skilled labor (such as mining technicians, engineers and managers); and 2) policy and institutional factors, including political stability and quality of governance (such as the likelihood of unexpected policy and regulatory changes, and the clarity and enforcement of regulations), FDI legislation and policy (such as protection and treatment of foreign investors, and the ability to repatriate profits), the nature and security of mining concessions or titles, and the level and structure of taxation. ${ }^{10}$

The benefits from renegotiation can go beyond revenue increases. Better relationships with NR extracting companies based on high quality contracts can help countries maximize the long-term economic benefits of NR by setting a framework for technology transfer, infrastructure development and sustainable environment. Cotula (2010) points out that joint ventures tend to give the host country greater opportunities for technology transfers, when compared to concessions and profit sharing agreements. He, however, reminds policy makers to consider the pros and cons of each contract in the specific context, since there are no silver bullets and the devil is in the detail. Sharing experiences between similar countries

\footnotetext{
10 The United Nations suggests that governments should make efforts to reduce uncertainty in order to successfully attract FDI, especially in terms of security of tenure, stability of exploration/mining terms, ability to predetermine tax liability, and ability to predetermine environmental obligations (Otto, 1992). In the context of PNG, it is important to encourage the training of specialized engineers and mine technicians; and, gradually and transparently, adjust tax and regulatory policy when necessary, taking into account investments under previous regimes (United Nations 2011, "Lessons for mineral-rich developing countries and policymakers").
} 
or other forms of regional cooperation would help NR-abundant countries build their capacity to negotiate with experienced foreign extracting companies.

Additionally, in order to avoid dependency on the country's natural resource sector, it is important to consider diversification of investments and attraction of FDI in other sectors of the economy. For instance, Alfaro (2003) suggests that FDI spillovers in manufacturing are greater than in the primary sector, mainly because multinationals' intensive use of intermediate goods enhances production efficiency in host economies, increasing demand for inputs that can be supplied by local companies. Therefore the PNG government should do more to promote FDI flows to other sectors of the economy, and facilitate linkages between current foreign investors and local companies.

\subsection{Improving exchange rate policies}

It might be expected that monetary policy can be used to prevent currency appreciation, and thereby ease symptoms of Dutch disease; however, when faced with export driven appreciation the effectiveness of monetary policy will be limited, as Magud and Sosa (2010) argue.

However, this does not mean that monetary policy is impotent. Frankel (2012) recommends dampening nominal currency appreciation by adding to foreign exchange reserves, when the appreciation pressure doesn't seem long-lasting. However, if the boom is long-lasting, he recommends allowing more exchange rate flexibility and accommodating the shift into the terms of trade even though it means sacrificing the exchange rate as a nominal anchor for monetary policy. In line with this discussion, an NRF (e.g. PNG's SWF) can help mitigate currency appreciation pressure by investing the fund in foreign assets (World Bank, 2010). That is especially worthwhile when foreign investments from this fund are made during short-term highs in NR prices. 


\subsection{More effective spending of natural resource revenue}

According to the PNG Minister of Finance, the PNG government has already introduced several policies to enhance the efficiency of public investments by, for instance, setting new project contract procedures, a Services Improvement Program and a Project Management Program. However, PNG's governance quality and its progress toward improvement are generally viewed skeptically since PNG, in partnership with donor countries, has a long history of struggling to improve governance, with no clear results (Teskey, 2013).

To improve governance and institutions, and to accomplish effective public investment, PNG should establish a workable accountability system. ${ }^{11}$ Given that this is the most important challenge for the country, we explore this issue in more detail below.

Establishing an accountability system involving effective checks from outside the government is difficult to achieve in a country with weak governance, institutions afflicted by corruption, and without a democratic culture in civil society. ${ }^{12}$ Furthermore, we cannot expect that simply introducing an accountability system modeled on those in developed economies will work well in the case of PNG.

In this section, we explore three policy options to enhance transparency in revenue collection and spending: a direct cash transfer program, adoption of the Extractive Industries Transparency Initiatives (EITI), and an auditing working group consisting of government staff and non-governmental members who oversee the efficiency in NR revenue collection and spending.

\subsubsection{Direct cash transfer program}

Direct cash transfer of NR revenues is a relatively new policy aiming to achieve more efficient spending and enhance accountability. Moss (2011) insists that direct cash transfer can give citizens incentives to monitor the government's NR revenue management and by strengthening citizens' economic relationship with the government. International examples of

\footnotetext{
${ }^{11}$ In addition to the absence of an effective accountability system, the lack of government's capacity to properly utilize NR revenues might be another problem for PNG. Although this cannot be improved in the short-term, support from international organizations and personnel exchange programs with other countries may help PNG's government.

12 It is important to acknowledge here that PNG's society has been recently changing their attitude towards the government. For example, Morris (2011) believes that social media such as Facebook and Twitter can make PNG citizens' political participation easier and more influential.
} 
this program include Progresa-Oportunidades in Mexico and Bolsa Familia in Brazil (Moss, 2011).

Although we recognize the advantages of a direct cash transfer program and the importance of providing economic incentives for citizens to place a check on their government, we do not consider that a direct cash transfer is the best policy for PNG. In the context of African countries' development, Booth (2012) argues that citizens' pressure on government does not lead to better public policies, but results in more clientelism under typical conditions. We should be aware of the possibility that something similar could happen in PNG, where civil society remains limited. In addition, direct cash transfer requires developed financial institutions and greater financial literacy among citizens, conditions which do not hold in PNG. ${ }^{13}$ Furthermore, a direct cash transfer program may be unable to provide sufficient public goods necessary for long-term development, since it does not solve the collective action problem of public good provision. This point is very relevant to PNG, where geographical fragmentation -including remote islands with many mountainous areasrequires more investment in infrastructure such as roads, ports, and airports, and where growing population increases the need for public education.

\subsubsection{Extractive Industries Transparency Initiatives (EITI)}

One of the most widely known initiatives to improve NR revenue management is the Extractive Industries Transparency Index (EITI). EITI is an international initiative that seeks to improve the transparency of NR revenue flows by defining criteria that participant countries should follow in collaboration with its civil society and extraction firms. EITI's criteria include, among others:

- Regular publication of all material oil, gas and mining payments by companies to governments and all material revenues received by governments from oil, gas and mining companies to a wide audience in a publicly accessible, comprehensive and comprehensible manner.

- Civil society is actively engaged as a participant in the design, monitoring and evaluation of this process and contributes towards public debate.

\footnotetext{
13 There are claims that PNG has become more suitable to implement a direct cash transfer program. Duncan (2010) suggests that "the extensive coverage of mobile phones in Papua New Guinea and the developing use of mobile phone banking, the improved registration of births and deaths, and, very significantly, the recently amended ILG Act, which provides the grassroots with a base for updating details of all individuals in a social unit" makes direct cash transfer more feasible.
} 
EITI has already been implemented in more than 30 countries, and has contributed, to some extent, to higher transparency and more recognition for its necessity. However, the main criticism of EITI is that it has not reduced corruption levels because: (1) the level of transparency required in EITI is insufficient, (2) the scope of the rule is too focused on the material payments between government and companies, and thus significant problems relating to the NR management are not addressed, and (3) EITI assumes a strong and active civil society: but transparency alone is insufficient when civil society is not accustomed to utilize information to hold government accountable (Olcer, 2009). Because of these deficiencies, we consider that EITI's requirements are not sufficient for PNG, where the central concern is not related to the transparency of cash flows from extracting companies but the effective spending of NR revenues. ${ }^{14}$

\subsubsection{An auditing working group with non-governmental members}

Instead of, or in addition to, EITI, we recommend that PNG establishes an auditing working group to oversee government departments and agencies in terms of the accuracy and efficiency of NR revenue management, including NR revenue collection and spending. ${ }^{15}$ This group would consist of government staff and non-governmental members, including representatives of civil society like professional experts. Independent international experts should also be invited to participate. We call this organization the Accountability in Natural Resource Management Working Group (ANRMWG). ANRMWG's operation would have two main goals: advice and monitoring. The primary role of the ANRMWG would be evaluative and advisory. It would benchmark PNG against international best practice and provide advice on NR management drawing on local and international expertise. Second, ANRMWG would periodically and publicly report on both NR-revenues and expenditures, providing valuable public information that will enhance the ability of civil society to hold government to account.

This working group would have two advantages in PNG's current situation. First, is its broad scope. The target of the working group's auditing would not be limited to NR revenue collection, but also cover NR revenue spending, which is currently the most problematic process today in PNG. Second, the composition of membership. Members of ANRMWG would consist of governmental staff and non-governmental representatives, especially

${ }^{14}$ There are still some areas where PNG should improve the NR revenue reporting, such as non-tax payments by extracting companies to landowners and provincial governments, and off-budget transactions through State Owned Enterprises (Morris, 2009).

15 "NR revenue management" corresponds to the link 3 (collection of taxes and royalties), link 4 (revenue management and allocation) and link 5 (implementation of development policy and project) in the Value Chain Approach (Alba, 2009) and our recommendation shares the basic motive with EITI++ announced by the World Bank (2008). 
experts, who can assess the government's NR management and exert pressure for improvements. In order to ensure the independence of ANRMWG, composition of the group will be important. A mixture of expert outside advisors and government officials should be appointed with fixed terms of tenure.

To some extent, PNG has already established a similar organization: the Board of the Sovereign Wealth Fund. The Board's function is to oversee the investment and management of the SWF in accordance with the law, including the determination of the investment strategy (SWF law Section 17). The six members of the Board are from the private sector.

Since the SWF law does not have clear guidelines about whether the Board can oversee expenditures after money is distributed from the SWF to outside entities (such as agencies and state owned enterprises), it is not clear whether the Board can function as an equivalent to an ANRMWG. Therefore we consider that PNG can improve the efficiency in NR revenue spending by creating a new ANRMWG or by transforming the Board to an ANRMWG.

If PNG considers this recommendation, the Nigerian Extractive Industries Transparency Initiative (NEITI) might be a potential example to follow. As Sala-i-Martin and Subramanian (2003) describe it, waste and leakage in the NR revenue distribution process was also a problem in Nigeria. In 2004, Nigerian President Obasanjo created the NEITI as a component of a broader reform program. NEITI's governing body, called the National Stakeholders Working Group (NSWG), consists of representatives of government, extractive companies, and civil society. NEITI's primary objectives, stipulated later in the NEITI act of 2007, include ensuring transparency and accountability by the government in the "application" of resources from payments received from extractive industry companies, in addition to the objectives required in the EITI rules. Thanks to its ambitious objectives and its status as the first country that became EITI compliant, NEITI is often referred to as a successful example of EITI. However, some are dubious of the NEITI's achievements. Shaxson (2009) insists that NEITI has not shown impressive results, and so far it is hard to see how better transparency has led, in turn, to better governance in Nigeria, regardless of its broader goals of fostering better governance and accountability. This point corresponds to our repeated claim that simple transparency can be insufficient in a less mature civil society. In addition, he suggests that NEITI lost its momentum after the general trend for reform slowed and political support from leaders weakened. 
Shaxson's second point is valid and demonstrates that, in order for ANRMWG to work, it must have strong and stable support from political leaders. This may sound paradoxical since, if the working group is strongly supported by the political leaders in government, effective pressure on government by the working group seems unlikely. We recognize this potential problem as an inevitable issue considering an institutional reform that does not mainly rely on pressure from citizens. However, we still expect ANRMWG to be feasible because PNG's government has demonstrated a commitment to improve the efficiency of spending. Creating an ANRMWG or making the SWF Board closer to an ANRMWG would be a natural extension of these on-going policies. Ultimately an effective ANRMWG would be an asset to the government as it could provide external validation of the effectiveness of government policies.

According to a local broadcasting network in PNG, the government is currently considering participating in EITI. ${ }^{16}$ We recommend PNG's government consider not merely participating in EITI, but creating an auditing working group like ANRMWG or transforming the SWF Board into an ANRMWG in order to improve the quality of governance and institutions and promote a more effective spending of NR revenues in the country.

${ }^{16}$ National EMTV (2013). 


\section{Conclusion}

Among the several challenges that PNG faces, the biggest and most imminent threat to the economy in the context of the NR curse is the country's weak governance and institutions, leading to ineffective use of NR-revenues. PNG's weak governance undermines the effect of the fiscal policies that seek to encourage the non-NR tradable sector. The key to improved governance and institutions is to establish an accountability system, involving effective checks from people outside the government. However, there is no easy way to create this level of accountability, especially in countries with less mature civil societies. Given the limitation of the other options, such as direct cash transfer programs and EITI, we recommend that the PNG government establish a working group consisting of government staff and non-governmental members, including professional experts, which would oversee the efficiency of the NR revenue collection and spending. It might be more feasible for PNG to accomplish this by extending the functions of the existing SWF board.

These challenges are not unique for PNG, but are shared by other countries in Asia and the Pacific. Savacool (2010) argues that countries in South East Asia share the following concerns: 1) resource extraction is anticipated to dramatically increase in the region, and 2) poor institutions are still prevalent in the region. It is true that countries in South East Asia, such as Malaysia, Thailand and Indonesia, have successfully reduced their reliance on natural resources by expanding exports of manufactures rather than agricultural and natural resource products (Coxhead, 2007). However, declines in the terms of trade in manufacturing and increases in the terms of trade in primary products, which began in the late 1990s, created incentives for commodity-producing countries in Asia and the Pacific to specialize further in primary products (UNESCAP, 2012).

Given this context, recommendations to PNG can be also applicable to other Asia-Pacific countries. Tailored country-specific policy options could be further developed based on the policies proposed in this paper in order to turn NR abundance into a blessing, and achieve sustainable economic growth. 


\section{References}

Aghion, Philippe, Bacchetta, Philippe, Rancie Romain and Rogoff, Kenneth, 2009, "Exchange rate volatility and productivity growth: The role of financial development" Journal of Monetary Economics, Vol. 56, pp494-513

Alba, Eleodoro Mayorga, 2009 "Extractive Industries Value Chain," Extractive Industries for Development Series \#3 Africa Region Working Paper Series \#125

Alfaro, Laura, 2003 “Foreign Direct Investment and Growth: Does the Sector Matter?”, available in http://www.grips.ac.jp/teacher/oono/hp/docu01/paper14.pdf

Alexeev, M., and Conrad, R. 2009 "The Elusive Curse of Oil." The Review of Economics and Statistics 91 (3): 586-98.

Auty, Richard, 1993, "Sustaining Development in Mineral Economies: The Resource Curse Thesis," Oxford University Press, New York

Auty, Richard and Mikesell, Raymond, 1998. "Sustainable Development in Mineral Economies" Clarendon Press, Oxford

Auty, Richard, 2001, "Resource Abundance and Economic Development, World Institute for Development Economics Research," Oxford University Press.

Bakani, Loi Martin, 2012. "Managing Resource Benefits," address at the Mining \& Petroleum Investment Conference 4 December 2012, Sydney, Australia, available in http://www.bankpng.gov.pg/speeches-mainmenu-95

Bank of Papua New Guinea. "Statistics," available in, http://www.bankpng.gov.pg/statistics-mainmenu-121/505-qeb-statistical-tables-sp-1 $\underline{8427}$

Banks, Glenn, 2008. “Understanding 'resource' conflicts in Papua New Guinea. Asia Pacific Viewpoint," Vol. 49, No. 1, April 2008 ISSN 1360-7456, pp23-34

Barker, Paul, 2011. "Papua New Guinea: Benefiting or losing out in commodity boons?", Development Policy Blog, Development Policy Center, available in http://devpolicy.org/papua-new-guinea-benefiting-or-losing-out-in-commodity-booms I

Batten, Aaron, 2012. "Growing the future, but can government manage the risks? PNG's 2013 Budget”, Development Policy Blog, Development Policy Center, available in http://devpolicy.org/growing-the-future-but-can-government-manage-the-risks-pngs2013-budget-20121212/

Blas, Javier, 2012. "Mexico hedges against oil price slide," Financial Times .com September 25,2012 , available in http://www.ft.com/cms/s/0/ab402292-072e-11e2-92b5-00144feabdc0.html\#axzz2Pb $\underline{4 x v B 3 F}$ 
Booth, David, 2012. "Development as a collective action problem Addressing the real challenges of African governance," Synthesis report of the Africa Power and Politics Programme (ISBN: 978-1-907288-94-4)

Brahmbhatt, M., O. Canuto, and E. Vostroknutova. 2010. "Natural Resources and Development Strategy after the Crisis." In The Day after Tomorrow: A Handbook on the Future of Economic Policies in the Developing World, ed. O. Canuto and M. Giugale 101-18," Washington, DC: World Bank.

Canuto, Otaviano and Cavallari, Matheus. 2012. "Natural Capital and the Resource Curse." Poverty Reduction And Economic Management (Prem) Network, No. 83, World Bank

Cashin, Paul, Ce'spedes, Luis F. and Sahay, Ratna. 2004. "Commodity currencies and the real exchange rate." Journal of Development Economics, Vol. 75, pp.239-268

Chamber of Mines and Petroleum PNG (a) (2013), "Mining in PNG" available in www.pngchamberminpet.com.pg/mining-in-png/; see also "Industry benefits" www.pngchamberminpet.com.pg/industry-contribution/

Chamber of Mines and Petroleum PNG (b) (2013), "Executive Director's Report" available in www.pngchamberminpet.com.pg/wordpress/wp-content/uploads/We12-05-2012-AG M Executive-Directors-Rpt.pdf

Clark Helen, 2011. "Avoiding the Resource Curse: Managing extractive industries for human development". Keynote Speech on United Nations Development Programme. Mongolia, 20-21 October 2011, available in http://www.undp.org/content/undp/en/home/presscenter/speeches/2011/10/20/helen -clark-avoiding-the-resource-curse-managing-extractive-industries-for-human-devel opment-.html

Collier, Paul, and Benedikt Goderis, 2007 "Commodity Prices, Growth and the Natural Resources Curse: Reconciling a Conundrum," CSAE Working Paper Series, No. 276, The Centre for the Study of African Economies, Oxford, UK.

Corden, M and J. P. Neary, 1982. "Booming Sector and Deindustrialization in Small Open Economy," The Economic Journal, 92:825-848

Coxhead, Ian, 2007. "A New Resource Curse? Impacts of China's Boom on Comparative Advantage and Resource Dependence in Southeast Asia,"World Development, Elsevier, vol. 35(7), pages 1099-1119, July.

Cotula, Lorenzo, 2010 "Investment contracts and sustainable development," ISBN: 978-1-84369-765-7, International Institute for Environment and Development. Department of Education PNG, 2012 "Implementation of 2012 Tuition Fee Free Education And Tuition Fee Subsidy Policy," available in 
http://www.education.gov.pg/QL News/

Department of Treasury PNG, 2013 "National Budget 2013: Economic and Development Policies", Volume 1, available in

http://www.treasury.gov.pg/html/national budget/files/2013/budget documents/Volu me1/Vol1.pdf

Duncan, Ron, 2010. "Managing natural resource revenues in Papua New Guinea," Spotlight with NRI, Vol. 4 No. 1

Egert, Balazs, 2012, "Dutch Disease in the post-soviet countries of Central and South-West Asia: How contagious is it?" Journal of Asian Economics, Vol. 23, pp571-584

Elek, Andrew, 2012 "The Papua New Guinea Experience: Some Issues from the Early Years of East Timor", mimeo

Elek, Andrew, 2012 “Dealing with Resource Riches: Papua New Guinea's Experience and Prospects" in "Blessing or curse. The rise of the mineral dependence among lowand middle-income countries", Chapter 13, mimeo.

Fosu, Augustin Kwasi, 2011 "Terms of Trade and Growth of Resource Economies: A Tale of Two Countries," CSAE Working Paper WPS/2011-09, Center for Study of African Economies, Department of Economics, University of Oxford.

Frankel, Jeffrey A. 2012. "The Natural Resource Curse: A Survey of Diagnoses and Some Prescriptions," HKS Faculty Research Working Paper Series RWP12-014, John F. Kennedy School of Government, Harvard University.

Frankel, Jeffrey, 2012, "A Solution to Fiscal Procyclicality: The Structural Budget Institutions Pioneered by Chile," Fiscal Policy and Macroeconomic Performance, Fourteenth Annual Conference of the Central Bank of Chile. NBER WP No. 16945.

Garnaut, Ross and Anthony Clunies Ross, 1983 "Taxation of mineral rents" Clarendon Press, Oxford ISBN 0-19-828454-3

Gylfason, T., 2001. "Natural Resources, Education, and Economic Development," European Economic Review 45: 847-59.

Gylfason, T. 2004, "Natural Resources and Economic Growth: From Dependence to Diversification," CEPR Discussion Paper 4804.

Howes, Stephen, 2013. "PNG in 2013: politics, economics, PNG-Australia relations, and Ross Garnaut," Policy Blog, Development Policy Center, available in http://devpolicy.org/png-in-2013-20120114/

Howes, Stephen. 2013 "Can PNG convert growth into development?" available in http://www.islandsbusiness.com/2013/2/business/can-png-convert-growth-into-deve lopment/

International Monetary Fund, 2012. "Papua New Guinea -- Staff Report for the 2012 Article IV 
Consultation," IMF Country Report No. 12/126

Ismail, Kareem. 2010. "The Structural Manifestation of the 'DutchDisease': The Case of Oil

Exporting Countries." IMF Working Paper WP/10/103

Kuwimb, Mako, 2010. "A critical study of the resource curse thesis and the experience of

Papua New Guinea," PhD thesis, James Cook University. (Chapters 10 and 11.)

Magud, Nicolás and Sosa, Sebastián, 2010. "When and Why Worry About Real Exchange

Rate Appreciation?," IMF Working Paper WP/10/271

Matsuyama, Kiminori, 1992, "Agricultural Productivity, Comparative Advantage, and

Economic Growth," Journal of Economic Theory 58, December, 317-334.

Mineral Resources Authority Papua New Guinea, 2013. available in, www.mra.gov.pg/

Morris, Matthew, 2011. "How can PNG fight the resource curse?," Development Policy Blog,

Development Policy Center, available in

http://devpolicy.org/how-can-png-fight-the-resource-curse/

Morris, Matthew, 2011. "Time to step up in PNG on Extractive Industries Transparency,"

Development Policy Blog, Development Policy Center, available in

http://devpolicy.org/time-to-step-up-on-extractive-industries-transparency/

Moss, Todd, 2011. "Oil to Cash: Fighting the Resource Curse through Cash Transfers,"

Center for Global Development Working Paper 237

National EMTV news March 14, 2013 "Government considering to implement EITI," available

in,http://www.emtv.com.pg/home/latest-news/item/government-considering-to-imple ment-eiti?category id $=20$

Ok Tedi Mining, 2013 "Key statistics," available in, www.oktedi.com/index.php?option=com content\&view=article\&id=48\&ltemid $=57$

Olcer, Dilan, 2009. "Extracting the maximum from the EITI," OECD Development Center Working Paper No. 276

Overseas Development Institute, 2006. "Meeting the Challenge of the 'Resource Curse'," available in,

http://www.odi.org.uk/sites/odi.org.uk/files/odi-assets/publications-opinion-files/839. pdf

Otto, James (1992). "A Global Survey of Mineral Company Investment Preferences." Mineral Investment Conditions in Selected Countries of the Asia-Pacific Region. New York: United Nations ST/ESCAP/1197.

Papua New Guinea Liquated Natural Gas PNG LNG, 2013. available in, www.pnglng.com/project/index.htm

Poelhekke, Steven, and, Frederick van der Ploeg, 2007, Volatility, Financial Development and the Natural Resource Curse," CEPR DP6513, October. 
PwC, 2013. "Working towards a better future: PNG National Budget 2013"

www.pwc.com/pg/en/budget-commentary/assets/2013 national budget - pwc co mmentary.pdf

Radon, Jenik, 2007. "How to Negotiate an Oil Agreement” in Escaping the Resource Curse (Initiative for Policy Dialogue), Chapter 4, ed. Humphreys, Macartan, Sachs, Jeffrey, and Stiglitz, Joseph. (Columbia University Press, 2007)

Reilly, Benjamin, 2008. "Ethic conflict in Papua New Guinea," Asia Pacific Viewpoint, Vol. 49, No. 1, April 2008 ISSN 1360-7456, pp12-22

Rielaender, Jan 2013. "Africa: Making the most of its natural resources," OECD Insight Debate the issue, available in http://insightsblog.oecdcode.org/?p=5607

Sachs, Jeffrey, 2007. "How to Handle the Macroeconomics of Oil Wealth," in Escaping the Resource Curse (Initiative for Policy Dialogue), Cpat. 7, ed. Humphreys, Macartan,

Sachs, Jeffrey, and Stiglitz, Joseph. (Columbia University Press, 2007)

Sachs, Jeffrey, and Andrew Warner, 1995, "Natural Resource Abundance and Economic Growth," in G. Meier and J. Rauch, eds., Leading Issues in Economic Development, New York: Oxford University Press. NBER WP 5398.

Sachs, Jeffrey, and Andrew Warner, 1999, "The big push, natural resource booms and growth." Journal of Development Economics, Vol. 19, pp43-76

Sala-i-Martin, Xavier, and Arvind Subramanian, 2003, "Addressing the Natural Resource Curse: An Illustration from Nigeria," IMF Working Paper WP/03/139.

Shaxson, Nicholas, 2009. "Nigeria's Extractive Industries Transparency Initiative Just a Glorious Audit?," Chatham House (ISBN 978186203219 4)

Stiglitz, Joseph E., 2012. "From Resource Curse to Blessing," available in http://www.project-syndicate.org/commentary/from-resource-curse-to-blessing-by-jo seph-e--stiglitz

Teskey, Graham, 2013. "Governance in PNG: what can donors do?," Development Policy Blog, Development Policy Center, available in http://devpolicy.org/governance-in-png-what-can-donors-do-20130124/

Tornell, A., and P. R. Lane. 1999. "The Voracity Effect," American Economic Review 89 (1): 22-46.

UNESCAP, 2011. "Sustaining Dynamism and Inclusive Development: Connecting in the Region and Productive Capacity in Least Developed Countries", Economic and Social Survey of Asia and the Pacific, United Nations publications

UNESCAP, 2012. "Living With High Commodity Prices.” Pursuing Shared Prosperity: In an Era of Turbulence and High Commodity Prices, Chapter 3, Economic and Social Survey of Asia and the Pacific 2012. 
UNCTAD, Statistics http://unctad.org/en/Pages/Home.aspx

World Bank, 2010. "Managing Resource Induced Volatility in Papua New Guinea: Some Issues for Discussion," Draft for discussion 68698

Yauieb, Anthony 2012. "Sovereign Wealth Fund" available in http://devpolicy.anu.edu.au/png-budget-project/budget-fora/ 


\section{Further Readings}

Asian Development Bank, Statistical Database System Online, available in, https://sdbs.adb.org/sdbs/index.jsp

Asian Development Bank, 2011" Asian Development Bank \& Papua New Guinea, Fact Sheet", available in, http://www.adb.org/sites/default/files/pub/2012/PNG.pdf

Bowman, Chakriya, 2005. "The Papua New Guinea Kina's Fear of Floating."

Brahmbhatt, M. \& Vostroknutova, E., 2010. "Development in a rapidly expanding natural resources sector: Challenges and policy potions for Lao LDR," Lao PDR

Development Report 2010, Natural Resources Management for Sustainable Development Chaudhury, Mamta Banu, 2004. "Resources boom and macroeconomic adjustments in developing countries", Ashgate Publishing Limited

Coutinho, Lenor. 2011. "The Resource Curse and Fiscal Policy," Cyprus Economic Policy Review, Vol. 5, No. 1, pp. 43-70 (2011) 1450-4561.

Easterly, William and Levine, Ross, 1997. "Africa's Growth Tragedy: Policies and Ethnic Divisions." Quarterly Journal of Economics, November 1997, 112 (4), pp. 1203 -50. International Labour Organization, 2008. "Decent Work Country Programme:

Papua New Guinea," available in,
http://www.ilo.org/public/english/bureau/program/dwcp/download/papua.pdf

Manzano, O. and Rigobón, R. 2007. "Resource Curse or Debt Overhang?” in Lederman, D. and Maloney, W. F., eds., Natural resources: neither curse nor destiny, Latin American Development Forum Series. pp. 41-70

Polterovich, V, Popov, V, and Tonis, A, 2010. "Resource abundance: A curse or blessing?," DESA Working Paper No. 93, ST/ESA/1010/DWP/93

Sachs, Jeffrey, and Andrew Warner, 2001, "The Curse of Natural Resources," European Economic Review (Elsevier), vol. 45(4-6), pages 827-838, May.

Sovacool, Benjamin K., 2010. "The political economy of oil and gas in Southeast Asia: heading towards the natural resource curse?," The Pacific Review, 23:2, 225-259

The Port Moresby Chamber of Commerce \& Industry “The PNG Investors' Manual A handbook for investing and doing business in Papua New Guinea" (2nd Ed.), available in http://www.pomcci.com/a/Resources/Doing-Business-in-PNG

U.S. Department of State, 2013. "Background Note: Papua New Guinea," available in, www.infoplease.com/country/profiles/papua-new-guinea.html

United Nations (2011) "Best Practices in Investment for Development," Investment Advisory Series Series B, number 7 .

Van der Ploeg, F. and Peolhekke, S., 2009. "Volatility and the natural resource curse," Oxford Economic Papers Vol. 61 No. 4 
World Bank, 2013. "World Bank Group and Partners Launch EITI++," World Bank Webpage, available in http://web.worldbank.org/WBSITE/EXTERNAL/COUNTRIES/AFRICAEXT/0,,conten tMDK:21727772 pagePK:146736 piPK:226340 theSitePK:258644,00.html World Bank's Pacific Department, 2011, "Discussion note: Pacific Futures," available in http://devpolicy.anu.edu.au/publications/reports.php

World Trade Organization (2013) "Papua New Guinea and the WTO" in Member Information, last visited $\quad$ February 23, 2013, available in http://www.wto.org/english/thewto_e/countries_e/papua_new_guinea_e.htm 


\section{ARTNeT Working Paper Series}

is available at www.artnetontrade.org

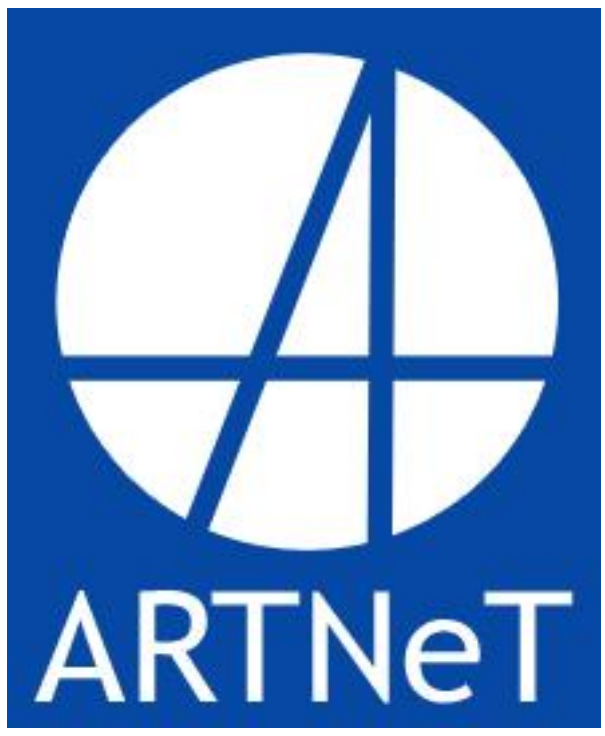

ARTNeT Secretariat

United Nations

Economic and Social Commission

for Asia and the Pacific

Trade and Investment Division

United Nations Building

Rajadamnern Nok Avenue

Bangkok 10200, Thailand

Tel: +66 (0)2-288-2251

Fax: +66(0)2-288-1027

Email: artnetontrade@un.org

Website: www.artnetontrade.org 